\title{
Rapid acidification of mode and intermediate waters in the southwestern Atlantic Ocean
}

\author{
L. A. Salt ${ }^{1, *}$, S. M. A. C. van Heuven ${ }^{2, * *}$, M. E. Claus $^{3}$, E. M. Jones ${ }^{4}$, and H. J. W. de Baar ${ }^{1,3}$ \\ ${ }^{1}$ Royal Netherlands Institute for Sea Research, Landsdiep 4, 1797 SZ, Texel, the Netherlands \\ ${ }^{2}$ Centre for Isotope Research, University of Groningen, Nijenborgh 4, 9747 AG, Groningen, the Netherlands \\ ${ }^{3}$ Department of Ocean Ecosystems, University of Groningen, Nijenborgh 7, 9747 AG, Groningen, the Netherlands \\ ${ }^{4}$ Alfred Wegener Institute for Polar and Marine Research, 120161, 27515, Bremerhaven, Germany \\ *now at: CNRS, UMR7144, Equipe Chimie Marine, Station Biologique de Roscoff, Place Georges Teissier, \\ 29680 Roscoff, France \\ ** now at: Alfred Wegner Institute, Climate Sciences Department, Postfach 120161, 27515 Bremerhaven, Germany
}

Correspondence to: L. A. Salt (lesley.salt@sb-roscoff.fr)

Received: 20 March 2014 - Published in Biogeosciences Discuss.: 12 May 2014

Revised: 16 January 2015 - Accepted: 19 January 2015 - Published: 5 March 2015

\begin{abstract}
Observations along the southwestern Atlantic WOCE A17 line made during the Dutch GEOTRACESNL programme (2010-2011) were compared with historical data from 1994 to quantify the changes in the anthropogenic component of the total pool of dissolved inorganic carbon $\left(\Delta \mathrm{C}_{\mathrm{ant}}\right)$. Application of the extended multilinear regression (eMLR) method shows that the $\Delta \mathrm{C}_{\mathrm{ant}}$ from 1994 to 2011 has largely remained confined to the upper 1000 dbar. The greatest changes occur in the upper $200 \mathrm{dbar}$ in the Subantarctic Zone (SAZ), where a maximum increase of $37 \mu \mathrm{mol} \mathrm{kg}^{-1}$ is found. South Atlantic Central Water (SACW) experienced the highest rate of increase in $\mathrm{C}_{\mathrm{ant}}$, at $0.99 \pm 0.14 \mu \mathrm{mol} \mathrm{kg}^{-1} \mathrm{yr}^{-1}$, resulting in a maximum rate of decrease in $\mathrm{pH}$ of $0.0016 \mathrm{yr}^{-1}$. The highest rates of acidification relative to $\Delta \mathrm{C}_{\mathrm{ant}}$, however, were found in Subantarctic Mode Water (SAMW) and Antarctic Intermediate Water (AAIW). The low buffering capacity of SAMW and AAIW combined with their relatively high rates of $\mathrm{C}_{\mathrm{ant}}$ increase of $0.53 \pm 0.11$ and $0.36 \pm 0.06 \mu \mathrm{mol} \mathrm{kg}^{-1} \mathrm{yr}^{-1}$, respectively, has lead to rapid acidification in the SAZ, and will continue to do so whilst simultaneously reducing the chemical buffering capacity of this significant $\mathrm{CO}_{2}$ sink.
\end{abstract}

\section{Introduction}

The Atlantic Ocean contains the largest store of anthropogenic carbon $\left(\mathrm{C}_{\mathrm{ant}}\right)$ of all the world's oceans, accounting for approximately $38 \%$ of the total $\mathrm{C}_{\text {ant }}$ inventory (Sabine et al., 2004). Within the Atlantic, the North Atlantic has been found to be responsible for the majority of the uptake of $\mathrm{C}_{\mathrm{ant}}$, due to the formation of North Atlantic Deep Water (NADW; Lee et al., 2003; Sabine et al., 2004). However, a recent Atlantic Basin inventory analysis indicates that in the past decade the South Atlantic has been more effective at sequestering $C_{\text {ant }}$ (Wanninkhof et al., 2010) than the North Atlantic. These authors calculated a rate of increase in the North Atlantic inventory of $1.9 \mathrm{Pg} \mathrm{C}_{\text {decade }}-1$, whereas the South Atlantic inventory grew at a rate of $3.0 \mathrm{Pg} \mathrm{C}$ decade $^{-1}$. Calculations by Ríos et al. (2012) indicate that the southwestern Atlantic Ocean dominates the South Atlantic sink of $\mathrm{C}_{\mathrm{ant}}$, with a storage rate of $0.25 \pm 0.035 \mathrm{Pg} \mathrm{C}_{\text {decade }}{ }^{-1}$. Quantifying the exact rate of increase in anthropogenic carbon in ocean waters is inherently problematic due to the highly variable nature of dissolved inorganic carbon (DIC) within the ocean and the relatively small fraction of total DIC that the anthropogenic component represents $(\sim 3 \%$; Ríos et al., 2010). In the past decade, a number of methods for calculating the increase in $\mathrm{C}_{\mathrm{ant}}\left(\Delta \mathrm{C}_{\mathrm{ant}}\right)$ between reoccupation of ocean transects have been developed (TrOCA, $\phi \mathrm{C}_{\mathrm{T}}^{0}$, eMLR). Despite the differing approaches and assumptions, there is overall coherence in the determinations of the anthropogenic 
component of inorganic carbon in the Atlantic Ocean (Lee et al., 2003; Vázquez-Rodríguez et al., 2009a; Peng and Wanninkhof, 2010; Wanninkhof et al., 2010).

The southwestern Atlantic has been occupied several times over the past 20 years, and several techniques to determine $\mathrm{C}_{\mathrm{ant}}$ have been applied to the WOCE ' 94 A17 transect by Ríos et al. (2010). These methods included $\Delta C^{*}$ (Gruber et al., 1996), TrOCA (Tracer combining Oxygen, inorganic Carbon and total Alkalinity; Touratier et al., 2007), $\phi \mathrm{CT}^{\circ}$ (Vázquez-Rodríguez et al., 2009a), and TTD (transit time distributions; Waugh et al., 2006) and showed general conformity in the distribution of $\mathrm{C}_{\mathrm{ant}}$. The presence of the western boundary current in the South Atlantic Ocean means that the $\mathrm{C}_{\mathrm{ant}}$ signal penetrates deeper and is larger in the western half of the basin compared to the eastern half (Wanninkhof et al., 2010; Ríos et al., 2010; Vázquez-Rodríguez et al., 2009a). Similarly, Murata et al. (2008) show that the $\mathrm{C}_{\text {ant }}$ signal in Subantarctic Mode Water (SAMW) can be $\sim 7 \mu \mathrm{mol} \mathrm{kg}{ }^{-1}$ higher west of $15^{\circ} \mathrm{W}$ compared to the east. Mode and intermediate water formation constitute a major pathway of $\mathrm{C}_{\mathrm{ant}}$ into the South Atlantic Ocean interior (McNeil et al., 2001; Sabine et al., 2004). The SAMW is formed in the Subantarctic Zone (SAZ), between the Subtropical Front (STF) and Subantarctic Front (SAF), where a calculated anthropogenic $\mathrm{CO}_{2}$ uptake of $0.07-0.08 \mathrm{PgC} \mathrm{yr}^{-1}$ occurs (Sabine et al., 1999; McNeil et al., 2001). A total $\mathrm{CO}_{2}$ sink of $1.1 \mathrm{Pg} \mathrm{Cyr}^{-1}$ was calculated by McNeil et al. (2007) for the SAZ, making it the largest $\mathrm{CO}_{2}$ sink in the Southern Ocean and a significant sink for anthropogenic atmospheric $\mathrm{CO}_{2}$.

The increase in DIC that results from the uptake of anthropogenic $\mathrm{CO}_{2}$ from the atmosphere leads to increasing proton, bicarbonate ion and carbon dioxide concentrations $\left(\left[\mathrm{H}^{+}\right],\left[\mathrm{HCO}_{3}^{-}\right],\left[\mathrm{CO}_{2}\right]\right)$ and decreasing carbonate concentrations $\left(\left[\mathrm{CO}_{3}^{2-}\right]\right)$, a process referred to as ocean acidification. Sabine et al. (2004) state that approximately $50 \%$ of the total amount of $\mathrm{C}_{\mathrm{ant}}$ in the world's oceans resides in the upper $400 \mathrm{~m}$. The associated decrease in $\mathrm{pH}$ has been calculated as $0.1 \mathrm{pH}$ units in the surface ocean relative to preindustrial times (Orr et al., 2005) and is ongoing. In the North Atlantic Ocean, observations have found acidification rates of $0.0016 \pm 0.0001$ and $0.0012 \pm 0.002 \mathrm{yr}^{-1}$ for Subarctic Intermediate Water (SAIW) and Subpolar Mode Water (SPMW), respectively (Vázquez-Rodríguez et al., 2012). Data from the European Time Series in the Canary Islands (ESTOC) station show significantly higher rates of $\mathrm{pH}$ decrease in surface waters of $0.0017 \pm 0.0004 \mathrm{yr}^{-1}$ for the time period 1995 to 2004, with notable influence from regional climatic forcing (Santana-Casiano et al., 2007). Acidification rates that deviate from the rate that is expected from $\mathrm{C}_{\mathrm{ant}}$ increases alone have been observed in upper Labrador Sea Water (uLSW), SAIW, and eastern North Atlantic Central Water (eNACW; Vázquez-Rodríguez et al., 2012). These variations have been attributed to a combination of climatic and biolog- ical effects. The greater sensitivity of some water masses to acidification has been well documented by González-Dávila et al. (2011) through the application of the buffering factors described by Egleston et al. (2010). González-Dávila et al. (2011) highlighted waters originating at high latitudes as particularly sensitive to increases in the concentration of dissolved $\mathrm{CO}_{2}\left(\left[\mathrm{CO}_{2}(\mathrm{aq})\right]\right)$, in particular Antarctic Intermediate Water (AAIW) and upper Circumpolar Deep Water $(u \mathrm{CDW})$ due to low ratios of total alkalinity $\left(A_{\mathrm{T}}\right)$ to DIC.

A number of the biological consequences of ocean acidification are related to the changes in carbonate, and thus calcium carbonate $\left(\mathrm{CaCO}_{3}\right)$, ion concentration. Carbonate ions are used by marine calcifying organisms to form both varieties of calcium carbonate: aragonite (e.g. by pteropods) and calcite (e.g. by coccolithophores and foraminifera). Aragonite is the less metastable form of $\mathrm{CaCO}_{3}$ resulting in a saturation horizon $\left(\Omega_{\mathrm{Ar}}=1\right)$ approximately $2 \mathrm{~km}$ shallower than that of calcite in the South Atlantic Ocean, below which depth the $\mathrm{CaCO}_{3}$ present will be in dissolved form. A number of experiments have observed shell dissolution in pteropods incubated at elevated partial pressure of $\mathrm{CO}_{2}\left(p \mathrm{CO}_{2}\right)$ (Orr et al., 2005; Lischka et al., 2011) associated with a lowering of the aragonite saturation state. Recently similar results have been observed in situ in the Southern Ocean (Bednaršek et al., 2012), indicating that species are already being affected by $\mathrm{C}_{\text {ant }}$ accumulation. Organisms that use aragonite are thus much more vulnerable to decreases in $\left[\mathrm{CO}_{3}^{2-}\right]$ driven from the surface increase in $\left[\mathrm{CO}_{2}\right]$.

This study examines the increase in $\mathrm{C}_{\mathrm{ant}}$ in the southwestern Atlantic Ocean between two occupations of the WOCE A17 line, which took place in 1994 and 2010/2011. We calculate the changes in $\mathrm{C}_{\mathrm{ant}}\left(\Delta \mathrm{C}_{\mathrm{ant}}\right)$ in the different water masses and subsequently examine the $\mathrm{pH}$ changes driven by the invasion of anthropogenic carbon between WOCE '94 A17 and GEOTRACES-NL (2010/2011). These results are furthermore put into context with regard to the differing buffering capacities of individual water masses.

\section{Data}

The two data sets used in this study are the results from the $\mathrm{CO}_{2}$ survey data from the WOCE '94 A17 section (public data at http://cdiac.ornl.gov/oceans/woce_a17c.html) and the Dutch West Atlantic GEOTRACES programme, completed in 2011 (GEOTRACES-NL, 2010/2011; public data available at http://www.bodc.ac.uk/geotraces/data/idp2014/). The respective stations from the two campaigns are shown in Fig. 1. The GEOTRACES-NL (2010/2011) section was carried out in two parts. The shown stations north of the Equator were occupied in July 2010 by the Dutch RV Pelagia (expedition 64PE321: from Hamilton, Bermuda, to Fortaleza, Brazil), and the Southern Hemisphere was sampled during March 2011 by the British RRS James Cook (JC057: from Punta Arenas, Chile, to Las Palmas, Gran Canaria). 


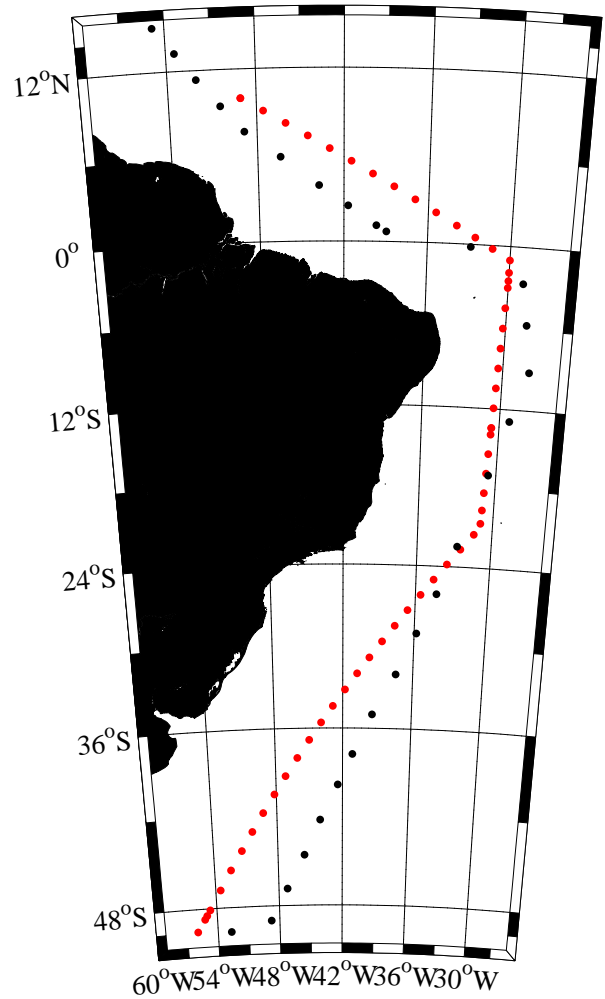

Figure 1. Stations where DIC and $A_{\mathrm{T}}$ samples were taken from both cruises (black represents the WOCE '94 A17 stations; red represents the GEOTRACES-NL (2010/2011) expeditions).

\subsection{WOCE '94 A17 measurements}

The WOCE '94 A17 section was similarly carried out in austral autumn, and these data have undergone rigorous quality control (Key et al., 2010). The data report is available from http://cdiac.ornl.gov/oceans/ndp_084/ (Ríos et al., 2005), where an offset of $-8 \mu \mathrm{mol} \mathrm{kg}^{-1}$ in the total alkalinity $\left(A_{\mathrm{T}}\right)$ data has been reported and corrected for in this study. From this data set, only the stations where data for both $A_{\mathrm{T}}$ and DIC are available were used. This resulted in a total of 59 stations and 1683 data points. For a detailed analysis of the WOCE occupation we refer the reader to Ríos et al. (2010).

\subsection{GEOTRACES-NL (2010/2011) measurements}

\subsubsection{Dissolved inorganic carbon and total alkalinity}

During the GEOTRACES-NL (2010/2011) cruises, for measurements of DIC and $A_{\mathrm{T}}$, water samples of $600 \mathrm{~mL}$ were collected from throughout the water column from 24 Niskin samplers mounted on a CTD rosette, following standard operating procedures (Dickson et al., 2007). At least two duplicates samples from different parts of the profile were collected at each station. Samples were simultaneously analysed immediately after collection on a VINDTA 3C (Versatile INstrument for the Determination of Total Alkalin-
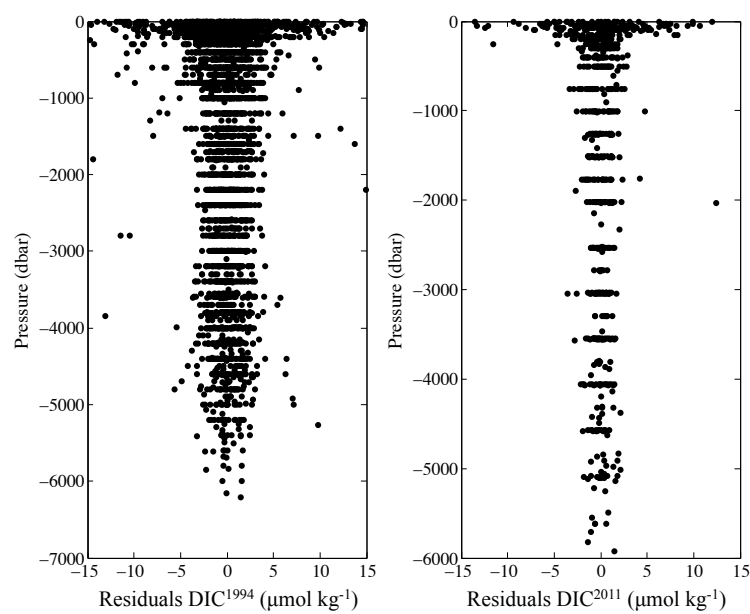

Figure 2. The residuals of the MLR fits of the (a) WOCE '94 A17 and (b) GEOTRACES-NL (2010/2011) data sets.

ity; Marianda, Kiel) system. This system determines DIC by coulometric titration using a coulometer (Johnson et al., 1987) and determines $A_{\mathrm{T}}$ by potentiometric titration with $0.1 \mathrm{M}$ hydrochloric acid (Mintrop et al., 2000). Quality control was performed through regular measurements of certified reference material (CRM, batch \#100) supplied by Andrew Dickson at Scripps Institute of Oceanography (San Diego, California). Based on the measurements performed on the CRM throughout both cruises, DIC was measured with a precision of $\pm 1.0 \mu \mathrm{mol} \mathrm{kg}^{-1}$ and the precision of $A_{\mathrm{T}}$ was $\pm 1.1 \mu \mathrm{mol} \mathrm{kg}{ }^{-1}$.

\subsubsection{Ancillary parameters}

Dissolved oxygen samples were collected from a minimum of three depths throughout the water column for CTD sensor calibration. Inorganic nutrients $\left(\mathrm{PO}_{4}, \mathrm{Si}(\mathrm{OH})_{4}, \mathrm{NO}_{3}\right)$ were analysed following the methods of Grasshoff et al. (1983). In every run, a control and a naturally sterilized reference nutrient sample (RMNS, Kanso, Japan) were measured for validation. Precision was estimated to be $\pm 0.01,0.2$ and $0.2 \mu \mathrm{mol} \mathrm{L}^{-1}$ for $\mathrm{PO}_{4}, \mathrm{Si}(\mathrm{OH})_{4}$ and $\mathrm{NO}_{3}$, respectively. Values of salinity are reported on the practical salinity scale.

\subsection{3 pH calculations}

From DIC, $A_{\mathrm{T}}$ and supplementary data (salinity, temperature, pressure, $\left.\mathrm{Si}(\mathrm{OH})_{4}, \mathrm{PO}_{4}\right), \mathrm{pH}$, and $p \mathrm{CO}_{2}$ were also calculated in situ for both data sets using CO2_SYS (Lewis and Wallace, 1998) adapted for MATLAB (van Heuven, 2011a), applying the acid dissociation constants of Mehrbach et al. (1973), refitted by Dickson and Millero (1987), and the $\mathrm{KSO}_{4}$ constant of Dickson (1990). Identical calculations were carried out on $A_{\mathrm{T}}$ and DIC data from both the WOCE '94 A17 and GEOTRACES-NL (2010/2011) data sets, with the resulting $\mathrm{pH}$ reported on the total $\mathrm{pH}$ scale. 


\subsection{Consistency between data sets}

In a later section, we employ the extended multi-linear regression (eMLR) method (Wallace, 1995; Friis et al., 2005) to infer $\Delta \mathrm{C}_{\mathrm{ant}}$ between the two cruises. The eMLR method considers various biogeochemical properties (in this case salinity, DIC, $\mathrm{NO}_{3}, \mathrm{Si}(\mathrm{OH})_{4}$ and apparent oxygen utilization $\left.\left(\mathrm{AOU}=\left[\mathrm{O}_{2}\right]_{\mathrm{sat}}-\left[\mathrm{O}_{2}\right]_{\mathrm{obs}}\right)\right)$ and is particularly sensitive to large-scale ("secular") changes in the distributions of these properties, as well as to analytical biases in their measurement. In order to assess the magnitude and distributions of these changes, we gridded the values of salinity, DIC, $\mathrm{NO}_{3}, \mathrm{Si}(\mathrm{OH})_{4}$ and $\mathrm{AOU}$ of each data set, and the gridded WOCE data set was subtracted from the GEOTRACES grid. Grid spacing was every $2^{\circ}$ of latitude, with 80 layers in the vertical direction, with increased density towards the surface. In the lower Circumpolar Deep Water $(l \mathrm{CDW}$; conceivably the most stable water mass in the section), the differences average $-0.01 \pm 0.015$ (salinity), $-4.2 \pm 12.1$ (DIC), $-1.92 \pm 0.78\left(\mathrm{NO}_{3}\right),-5.05 \pm 3.3\left(\mathrm{Si}(\mathrm{OH})_{4}\right)$ and $-3.13 \pm 3.9 \mu \mathrm{mol} \mathrm{kg}{ }^{-1}$ (AOU).

By limiting the comparison to just $l \mathrm{CDW}$, the number of data points available is limited; as such, we further performed a more robust crossover analysis of the GEOTRACES 2010/2011 data set with data from the CARINA database (CARINA Group, 2009; Tanhua, 2010). This was done for all the tracers used at depths deeper than $3000 \mathrm{~m}$. We find an offset of $+1 \pm 0.8 \%$ for $\mathrm{NO}_{3},-1 \pm 0.5 \%$ for dissolved oxygen, $-0.004 \pm 0.001$ for salinity, $-1 \pm 0.3 \%$ for $\mathrm{Si}(\mathrm{OH})_{4}$, $+1.17 \pm 2.8 \mu \mathrm{mol} \mathrm{kg}^{-1}$ for DIC, and $+5.3 \pm 4.4 \mu \mathrm{mol} \mathrm{kg}{ }^{-1}$ for $A_{\mathrm{T}}$. These values are all within the threshold values of the CARINA synthesis (Key et al., 2010); thus no corrections were applied to our data.

\section{Methods}

\section{1 eMLR and $\mathrm{C}_{\text {ant }}$ calculations}

There are two general carbon data-based approaches for studying the increasing oceanic $\mathrm{C}_{\text {ant }}$. The first approach uses back-calculation techniques to obtain an estimate of preindustrial DIC concentration against which to compare current measurements. Methods from the second approach aim to determine the part of change in DIC between two specific time periods that is attributable to anthropogenic invasion. One example of each approach is employed in this study: eMLR (Friis et al., 2005) and $\phi \mathrm{C}_{\mathrm{T}}$ (Vázquez-Rodríguez et al., 2009a, b). Various comparison and evaluations of these and other methods are available in the literature (Levine et al., 2008; Yool et al., 2010; van Heuven et al., 2011b; Sabine and Tanhua, 2010).

\subsection{1 $\Delta \mathrm{C}_{\text {ant }}$ from eMLR}

The multi-linear regression approach to estimating anthropogenic $\mathrm{CO}_{2}$ invasion was introduced by Wallace (1995). It involves using a number of biogeochemical properties that are known to be related to DIC to fit a model of the observed DIC. As the relationships between DIC and these properties are expected not to change over time, the same statistical relationships can be applied to a second data set of later date. Differences between the thus "predicted" DIC and the observed DIC are attributed to the invasion of anthropogenic $\mathrm{CO}_{2}$. In the extended version (eMLR) developed by Friis et al. (2005), which is applied here, the DIC from two data sets is fitted to the same selection of properties from both data sets, and the difference between parameter coefficients is assumed to be predictive of the difference in $\mathrm{C}_{\mathrm{ant}}$ between the two cruises:

$$
\begin{aligned}
\Delta \mathrm{C}_{\mathrm{ant}}^{\mathrm{eMLR}} & =\mathrm{DIC}^{\mathrm{MLR} 2, t 2}-\mathrm{DIC}^{\mathrm{MLR} 1, t 1} \\
& =\left(a_{2}-a_{1}\right)+\left(b_{2}-b_{1}\right) \mathrm{SiO}_{2 t 2}+\left(c_{2}-c_{1}\right) \mathrm{NO}_{3 t 2} \\
& +\left(d_{2}-d_{1}\right) \mathrm{AOU}_{t 2}+\left(e_{2}-e_{1}\right) S_{t 2}+\left(f_{2}-f_{1}\right) T_{t 2} \\
& +\left(g_{2}-g_{1}\right) P_{t 2} .
\end{aligned}
$$

Following Eq. (2), we apply the back-calculation technique as the DIC data from the more recent GEOTRACES-NL (2010/2011) cruise demonstrate a greater precision. The properties used to predict DIC in the WOCE '94 data set result in an $R^{2}$ value of 0.97 and a root-mean-square error (RMSE) of $10.7 \mu \mathrm{mol} \mathrm{kg}{ }^{-1}$. For the GEOTRACES-NL (2010/2011) data set a $R^{2}$ of 0.98 was obtained and an RMSE of $9.9 \mu \mathrm{mol} \mathrm{kg}^{-1}$ (Fig. 2).

The eMLR regressions were applied along isopycnal intervals, as the preferred method of water movement from the surface into the ocean interior is along surfaces of constant density. It thus follows that waters occupying the same density band share a common formation history and can be described by a single equation. Isopycnal bands were chosen based on temperature-salinity plots of the water masses and the amount of data occupying each interval. The coefficients and accompanying statistics from each isopycnal interval are displayed in Table 1a and b for the 1994 and 2010/2011 regressions, respectively. The residuals of each fit are shown in Fig. 2, with the 2011 data set showing an average of $2.1 \mu \mathrm{mol} \mathrm{kg}{ }^{-1}$ in the more stable deeper waters (> 2000 dbar). In comparison, the WOCE '94 A17 data set shows a deep-water (> 2000 dbar) column average residual of $3.17 \mu \mathrm{mol} \mathrm{kg}{ }^{-1}$, which we attribute to less precise measurements in the earlier data set. Pressure was included in the regression to avoid skewing (over depth) of the residuals of the MLR by the relatively large amount of samples located towards the surface, as mentioned by Hauck et al. (2010). 
Table 1a. Calculated coefficients for the performed multi linear regressions for each density interval using the (a) GEOTRACES-NL (2010/2011) data set and (b) WOCE'94 A17 data set. Differences between the coefficients were calculated following Eq. (2).

\begin{tabular}{|c|c|c|c|c|c|c|c|c|c|c|c|c|}
\hline $\begin{array}{l}\text { Min } \\
\text { density }\end{array}$ & $\begin{array}{r}\text { Max } \\
\text { density }\end{array}$ & $\begin{array}{r}\text { Mean layer } \\
\text { depth (m) }\end{array}$ & $a$ & $\mathrm{Si}(\mathrm{OH})_{4}$ & $\mathrm{NO}_{3}$ & Sal & Theta & $\mathrm{AOU}$ & Pressure & RMSE & $R^{2}$ & $n$ \\
\hline \multicolumn{13}{|c|}{ Sigma-theta } \\
\hline 20.0 & 23.5 & 31 & 131 & 1.61 & 33.91 & 56.25 & -4.78 & -0.08 & 0.208 & 7.6 & 0.98 & 90 \\
\hline 23.5 & 24.5 & 50 & 656 & -1.73 & 14.13 & 42.36 & -5.56 & 0.35 & -0.011 & 6.3 & 0.95 & 73 \\
\hline 24.5 & 25.0 & 53 & 152 & -23.36 & 17.86 & 60.70 & -11.33 & 0.22 & -0.262 & 5.0 & 0.99 & 23 \\
\hline 26.2 & 26.4 & 160 & 1206 & -0.35 & 1.36 & 26.14 & -3.38 & 0.57 & -0.017 & 2.1 & 1.00 & 45 \\
\hline 26.4 & 26.6 & 196 & 825 & -0.35 & 3.68 & 36.18 & -2.15 & 0.23 & 0.003 & 2.4 & 1.00 & 72 \\
\hline 26.6 & 26.8 & 259 & 1249 & -0.42 & 2.77 & 24.17 & -1.56 & 0.33 & -0.004 & 1.7 & 1.00 & 67 \\
\hline 26.8 & 27.0 & 310 & 1116 & -0.33 & 2.22 & 28.72 & -3.30 & 0.37 & -0.012 & 1.6 & 1.00 & 109 \\
\hline 27.0 & 27.2 & 431 & 1366 & 0.97 & 4.33 & 18.81 & 3.61 & 0.06 & -0.002 & 1.1 & 1.00 & 112 \\
\hline 27.2 & 27.4 & 672 & 601 & 0.45 & 3.58 & 42.68 & -3.07 & 0.16 & -0.004 & 2.1 & 0.99 & 96 \\
\hline 27.5 & 36.7 & 1108 & 2056 & 0.65 & -2.40 & 3.57 & -8.06 & 0.88 & -0.005 & 1.5 & 0.99 & 40 \\
\hline 36.7 & 36.8 & 1279 & 1471 & 0.88 & -3.58 & 20.18 & -7.86 & 1.05 & 0.003 & 1.0 & 1.00 & 44 \\
\hline 36.8 & 36.9 & 1531 & 4683 & 1.43 & -2.57 & -74.16 & 17.14 & 0.45 & 0.003 & 1.2 & 1.00 & 58 \\
\hline 36.9 & 36.9 & 1614 & 4840 & 1.12 & -2.24 & -77.82 & 10.87 & 0.45 & 0.001 & 1.2 & 1.00 & 31 \\
\hline 36.9 & 37.0 & 1946 & 7686 & 1.50 & -4.85 & -158.89 & 19.19 & 0.45 & 0.003 & 2.3 & 1.00 & 109 \\
\hline 37.0 & 37.1 & 2586 & 6937 & 0.90 & -3.65 & -137.01 & 8.11 & 0.63 & 0.002 & 0.7 & 1.00 & 71 \\
\hline \multicolumn{13}{|c|}{$4 \sigma$} \\
\hline 37.1 & 45.9 & 3050 & 1808 & 0.35 & 0.79 & 10.42 & -15.68 & 0.42 & -0.005 & 0.7 & 0.99 & 174 \\
\hline 45.9 & 46.0 & 3730 & 3087 & 0.29 & -0.49 & -27.18 & -8.62 & 0.75 & 0.001 & 1.2 & 1.00 & 122 \\
\hline 46.0 & 46.0 & 4195 & -14016 & 0.43 & 3.45 & 460.19 & -21.03 & 1.04 & 0.005 & 1.4 & 1.00 & 43 \\
\hline
\end{tabular}

\subsection{2 $\mathrm{C}_{\mathrm{ant}}$ from $\phi \mathrm{C}_{\mathrm{T}}{ }^{\circ}$}

The $\phi \mathrm{C}_{\mathrm{T}}{ }^{\circ}$ method is a back-calculation approach that uses stoichiometric ratios from biogeochemical processes to account for the addition of DIC in the water column resulting from organic matter remineralization and calcium carbonate dissolution since the time of water formation (VázquezRodríguez, 2008; Vázquez-Rodríguez et al. 2009a). It is based on the general principle of "preformed DIC" (or $\mathrm{C}_{\mathrm{T}}{ }^{\circ}$ ) of Brewer (1978) and $\Delta C^{*}$ of Gruber et al. (1996). The main advantage of this method is that it considers the non-steady state of $A_{\mathrm{T}}$ and $p \mathrm{CO}_{2}$ in the subsurface reference layer.

\subsection{Buffer factors}

The Revelle factor was originally described by Revelle and Suess (1957) and quantified the attenuated response of increasing DIC impacted by increasing $p \mathrm{CO}_{2}$, or vice versa. This work has been built upon by Egleston et al. (2010), who outlined six expressions that define how $\left[\mathrm{CO}_{2}\right],\left[\mathrm{H}^{+}\right]$, and $\Omega_{\mathrm{Ar}}$ or $\Omega_{\mathrm{Ca}}$ are impacted by changes in DIC or $A_{\mathrm{T}}$.
The following three expressions for the buffer factors relating to DIC were applied to the GEOTRACES-NL (2010/2011) and WOCE '94 A17 southwestern Atlantic sections (Eqs. 3-4 and 6-7 are taken from Egleston et al., 2010; however, Eqs. 5 and 8 are taken from Álvarez et al., 2014, who identified and corrected a typo in the definitions of Egleston et al., 2010). 
Table 1b. Continued.

\begin{tabular}{|c|c|c|c|c|c|c|c|c|c|c|c|c|}
\hline $\begin{array}{l}\text { Min } \\
\text { density }\end{array}$ & $\begin{array}{r}\text { Max } \\
\text { density }\end{array}$ & $\begin{array}{r}\text { Mean layer } \\
\text { depth }(\mathrm{m})\end{array}$ & $\mathrm{a}$ & $\mathrm{Si}(\mathrm{OH})_{4}$ & $\mathrm{NO}_{3}$ & Sal & Theta & AOU & Pressure & RMSE & $R^{2}$ & $n$ \\
\hline \multicolumn{13}{|c|}{ Sigma-theta } \\
\hline 20.0 & 23.5 & 31 & 263 & 7.28 & -96.35 & 43.77 & 5.95 & -0.20 & -0.047 & 8.6 & 0.92 & 42 \\
\hline 23.5 & 24.5 & 50 & 466 & -8.70 & 29.32 & 44.65 & -1.93 & 0.50 & 0.024 & 8.4 & 0.93 & 150 \\
\hline 24.5 & 25.0 & 53 & 1052 & -0.11 & 5.00 & 28.96 & -2.49 & 0.45 & 0.107 & 2.9 & 0.99 & 56 \\
\hline 25.0 & 25.4 & 57 & 1259 & -3.68 & 2.04 & 22.21 & -0.65 & 0.62 & 0.212 & 6.4 & 0.95 & 57 \\
\hline 25.4 & 26.2 & 107 & 974 & 1.55 & 2.21 & 31.43 & -2.76 & 0.53 & 0.061 & 6.8 & 0.98 & 137 \\
\hline 26.2 & 26.4 & 160 & 1097 & 0.62 & 2.93 & 27.82 & -1.96 & 0.43 & 0.008 & 3.8 & 0.99 & 75 \\
\hline 26.4 & 26.6 & 196 & 964 & 0.58 & 3.55 & 31.36 & -1.47 & 0.29 & 0.015 & 3.4 & 0.99 & 89 \\
\hline 26.6 & 26.8 & 259 & 1326 & 0.88 & 4.27 & 19.87 & 1.84 & 0.17 & 0.005 & 2.5 & 1.00 & 104 \\
\hline 26.8 & 27.0 & 310 & 1405 & 1.00 & 3.92 & 17.82 & 1.83 & 0.18 & -0.001 & 2.5 & 1.00 & 150 \\
\hline 27.0 & 27.2 & 431 & 1448 & 0.84 & 3.36 & 17.21 & 0.64 & 0.22 & -0.004 & 3.5 & 0.99 & 197 \\
\hline 27.2 & 27.4 & 672 & 1331 & 0.66 & 2.29 & 21.80 & -2.33 & 0.32 & -0.004 & 3.4 & 0.99 & 272 \\
\hline 27.4 & 27.5 & 991 & 1109 & 0.76 & 1.39 & 28.96 & -3.64 & 0.37 & -0.004 & 4.2 & 0.75 & 74 \\
\hline \multicolumn{13}{|c|}{$2 \sigma$} \\
\hline 27.5 & 36.7 & 1108 & 1915 & 0.41 & 1.44 & 5.68 & -3.05 & 0.37 & 0.005 & 2.0 & 0.98 & 90 \\
\hline 36.7 & 36.8 & 1279 & 1272 & 0.53 & 0.47 & 25.06 & -8.77 & 0.55 & -0.002 & 1.7 & 1.00 & 32 \\
\hline 36.8 & 36.9 & 1531 & 1473 & 0.76 & 1.57 & 18.17 & -0.31 & 0.30 & -0.003 & 5.3 & 0.98 & 105 \\
\hline 36.9 & 36.9 & 1614 & 3278 & 0.82 & 1.18 & -33.66 & 4.65 & 0.20 & -0.002 & 2.8 & 0.99 & 94 \\
\hline 36.9 & 37.0 & 1946 & 4372 & 0.76 & 1.43 & -65.08 & 5.14 & 0.11 & 0.001 & 2.2 & 1.00 & 226 \\
\hline 37.0 & 37.1 & 2586 & 3899 & 0.36 & 1.15 & -51.16 & -1.59 & 0.43 & 0.002 & 1.9 & 1.00 & 194 \\
\hline \multicolumn{13}{|c|}{$4 \sigma$} \\
\hline 37.1 & 45.9 & 3050 & 1335 & 0.53 & 2.11 & 21.83 & -2.35 & 0.29 & 0.002 & 1.7 & 0.98 & 145 \\
\hline 45.9 & 46.0 & 3730 & 3036 & 0.64 & 1.53 & -27.11 & 4.95 & 0.21 & 0.003 & 1.8 & 1.00 & 268 \\
\hline 46.0 & 46.0 & 4195 & 8008 & 0.09 & 1.73 & -168.68 & -0.95 & 0.23 & 0.003 & 2.6 & 0.99 & 75 \\
\hline 46.0 & 46.1 & 4582 & 810 & 0.06 & 0.32 & 38.12 & -13.29 & 0.77 & 0.005 & 3.0 & 0.60 & 165 \\
\hline 46.1 & 60.0 & 5108 & -5867 & 0.00 & 0.30 & 230.89 & -27.07 & 0.80 & 0.003 & 1.2 & 0.74 & 108 \\
\hline
\end{tabular}

\section{Hydrography of the South Atlantic Ocean}

$\gamma \mathrm{DIC}=\mathrm{DIC}-\mathrm{Alk}_{\mathrm{C}}^{2} / S$,

$\beta \mathrm{DIC}=\mathrm{DIC} \times S-\mathrm{Alk}_{\mathrm{C}}{ }^{2} / \mathrm{Alk}_{\mathrm{C}}$,

$\omega \mathrm{DIC}=\mathrm{DIC}-\left\{\mathrm{Alk}_{\mathrm{C}} \cdot\left(2 \cdot\left[\mathrm{CO}_{2}\right]+\left[\mathrm{HCO}_{3}^{-}\right]\right) / P\right\} t$,

where DIC $=\left[\mathrm{CO}_{2}\right]+\left[\mathrm{HCO}_{3}^{-}\right]+\left[\mathrm{CO}_{3}^{2-}\right]$,

$\mathrm{Alk}_{\mathrm{C}}=\left[\mathrm{HCO}_{3}^{-}\right]+2\left[\mathrm{CO}_{3}^{2-}\right]$,

$P=\left[\mathrm{HCO}_{3}^{-}\right]-\left\{\left[\mathrm{H}^{+}\right]\left[\mathrm{B}(\mathrm{OH})_{4}^{-}\right] / \mathrm{Khb}+\left[\mathrm{H}^{+}\right]\right\}$

$-\left[\mathrm{H}^{+}\right]+\left[\mathrm{OH}^{-}\right]$,

$S=\left[\mathrm{HCO}_{3}^{-}\right]+4\left[\mathrm{CO}_{3}^{2-}\right]+\left[\mathrm{H}^{+}\right]+\left[\mathrm{OH}^{-}\right]$

$+\left\{\left[\mathrm{H}^{+}\right]\left[\mathrm{B}(\mathrm{OH})_{4}^{-}\right] / \mathrm{Khb}+\left[\mathrm{H}^{+}\right]\right\}$

and $\Omega$ refers to the saturation state of sea water with respect to aragonite or calcite. These equations quantify the resistance to change of $\left[\mathrm{CO}^{2}\right](\gamma \mathrm{DIC}),\left[\mathrm{H}^{+}\right](\beta \mathrm{DIC})$ and $\Omega(\omega \mathrm{DIC})$ in a water mass to changes in DIC. The concentrations used for the calculations were obtained from CO2SYS (Lewis and Wallace, 1998, adapted for MATLAB by van Heuven, 2011a) using the same input conditions as previously mentioned (Sect. 2.2.3).
The distributions of potential temperature, salinity, AOU, silicate, $A_{\mathrm{T}}$ and DIC of the GEOTRACES-NL (2010/2011) section are shown in Fig. 3. The large water masses have been described elsewhere (Mémery et al., 2000; Ríos et al., 2010; Wanninkhof et al., 2010); thus the treatment is relatively concise here. Located deeper than 4500 dbar throughout the section is Antarctic Bottom Water (AABW), characteristic in its high DIC and AOU. Values for DIC in this water mass range from 2243 to $2267 \mu \mathrm{mol} \mathrm{kg}^{-1}$, and AOU values occupy a narrow band between 111 and $128 \mu \mathrm{mol} \mathrm{kg} \mathrm{kg}^{-1}$. The DIC maximum $\left(2267 \mu \mathrm{mol} \mathrm{kg}^{-1}\right)$ and potential temperature minimum $\left(-0.16^{\circ} \mathrm{C}\right)$ are both found in this water mass, which also shows the deep-water (>1000 dbar) $A_{\mathrm{T}}$ maximum $\left(2369 \mu \mathrm{mol} \mathrm{kg}{ }^{-1}\right)$. These characteristics are all representative of the old age of the water mass and are caused by the large amount of organic matter remineralization which has taken place within it. The AABW can most easily be distinguished from the overlying lower Circumpolar Deep Water $(l \mathrm{CDW})$ by the high silicate concentrations, which reach values greater than $120 \mathrm{umol} \mathrm{kg}^{-1}$ in AABW. Silicate con- 
centrations in the deep waters ( $>4000 \mathrm{dbar})$ demonstrate a strong covariance with $A_{\mathrm{T}}\left(R^{2}=0.95\right)$, which has been previously noted and stems from the simultaneous dissolution of opaline and calcium carbonate shells from the hard tissue of organisms (Pérez et al., 2002).

The $l \mathrm{CDW}$ has a core at approximately $3500 \mathrm{dbar}$ at $50^{\circ} \mathrm{S}$, above which it merges into $u \mathrm{CDW}$, with its respective core identified by an oxygen minimum at approximately $1500 \mathrm{~m}$ (Mémery et al., 2000). Both branches of CDW display properties similar to that of $\mathrm{AABW}$, as they represent a mixture of AABW and Weddell Sea Deep Water (Wong et al., 1999; Orsi et al., 1999). The $u$ CDW and lCDW share isopycnals with upper North Atlantic Deep Water $(u \mathrm{NADW})$ and lower North Atlantic Deep Water (lNADW), respectively, in the northern half of the section (Fig. 3a). The $u \mathrm{CDW}$ and $u \mathrm{NADW}$ occupy the density band between $\sigma_{\theta}>27.4$ and $\sigma_{3}<41.47$, with the front between the two water masses found at approximately $26^{\circ} \mathrm{N}$ (Mémery et al., 2000). The NADW has been more recently ventilated than CDW and is thus distinguished by lower AOU values of $\sim 60 \mu \mathrm{mol} \mathrm{kg}{ }^{-1}$ and DIC values lower than $2200 \mu \mathrm{mol} \mathrm{kg}{ }^{-1}$. The deeper $l$ NADW can be separated from $u$ NADW through higher silicate values, which rise to $40 \mu \mathrm{mol} \mathrm{kg}{ }^{-1}$, whereas $u$ NADW has maximum silicate concentrations of $20 \mu \mathrm{mol} \mathrm{kg}{ }^{-1}$ (Fig. 3d). The $A_{\mathrm{T}}$ values are also lower $\left(\sim 20 \mu \mathrm{mol} \mathrm{kg}^{-1}\right)$ in $u$ NADW compared to $l$ NADW.

The AAIW enters the section at 200 dbar just south of $48^{\circ} \mathrm{S}$, identifiable as a tongue of water with very low salinity and $A_{\mathrm{T}}$ (34.05 and $2275 \mu \mathrm{mol} \mathrm{kg}{ }^{-1}$, respectively, Fig. 3b). The AAIW lies above $u$ CDW and below SAMW (Peterson and Whitworth, 1989). This water mass is carried northward at intermediate depths between $\sigma_{\theta}>27.1$ and $\sigma_{\theta}<27.4$ (Ríos et al., 2012) from south of the SAF. In the southwestern Atlantic Ocean, AAIW extends further north than in other oceans, due to the western boundary current along the coast of South America (Talley, 1996). The AAIW is a relatively young water mass and has AOU values comparable to NADW $\left(\sim 50-100 \mu \mathrm{mol} \mathrm{kg}{ }^{-1}\right)$; however, it can be distinguished from $u$ NADW, in its northward reaches, by its elevated silicate concentrations. Situated above the AAIW, the SAMW is often considered a component of the AAIW (McCartney, 1977). This water mass can be easily identified by the tracer $\mathrm{Si}^{*}=\left[\mathrm{Si}(\mathrm{OH})_{4}\right]-\left[\mathrm{NO}_{3}^{-}\right]$, which has values from -10 to $-15 \mu \mathrm{mol} \mathrm{kg}^{-1}$ in regions of SAMW formation (Sarmiento et al., 2004). The SAMW formation region is located just south of $47^{\circ} \mathrm{S}$ in SAZ, north of the SAF (McCartney, 1977), where deep winter mixing forms this highoxygen water mass.

We locate the STF at $\sim 41^{\circ} \mathrm{S}$, where there is a steep gradient in salinity in the surface $200 \mathrm{dbar}$. North of the STF, in the surface, and extending northward to a density of $\sigma_{\theta}<26.5 \mathrm{~kg} \mathrm{~m}^{-3}$, is South Atlantic Central Water (SACW; Ríos et al., 2012), heavily depleted in silicate and with elevated salinity and $A_{\mathrm{T}}$. Against this background, the two Amazon plumes are very distinct at 5 and $15^{\circ} \mathrm{N}$, with salinity values of 34.11 and 32.3 and $A_{\mathrm{T}}$ values of 2265 and $2157 \mu \mathrm{mol} \mathrm{kg}^{-1}$, respectively. The maximum values of both salinity and $A_{\mathrm{T}}$ correspond to SACW in the subtropics $\left(17^{\circ} \mathrm{S}\right)$, reaching absolute maxima of 37.5 and $2456 \mu \mathrm{mol} \mathrm{kg}{ }^{-1}$, respectively, at $50 \mathrm{dbar}$ depth. The subtropical part of the SACW that features high salinity and $A_{\mathrm{T}}$ is often referred to as the Salinity Maximum Water (SMW). In this study we make no distinction between SMW and SACW.

\section{Results and discussion}

\subsection{Anthropogenic carbon in the southwestern Atlantic Ocean}

The distribution of $\mathrm{C}_{\mathrm{ant}}$ in 2011, calculated using the $\phi \mathrm{C}_{\mathrm{T}}{ }^{\circ}$ method (Vázquez-Rodríguez, 2009a), and the calculated increase in $\mathrm{C}_{\mathrm{ant}}\left(\Delta \mathrm{C}_{\mathrm{ant}}\right)$ from 1994 to 2011 , obtained from an eMLR analysis, are shown in Fig. $4 a$ and b, respectively. Both distributions show good consistency with previous studies (Ríos et al., 2010, 2012; Wanninkhof et al., 2010) and are not dissimilar from each other, with areas of high $\mathrm{C}_{\mathrm{ant}}$ also demonstrating the highest $\Delta \mathrm{C}_{\mathrm{ant}}$ from 1994 to 2010/2011. The total $C_{\text {ant }}$ (Fig. 4a) values show an increase in the surface waters compared to that of Ríos et al. (2010), calculated from the WOCE '94 A17 data set, which is consistent with the calculated $\Delta \mathrm{C}_{\mathrm{ant}}$ presented here (Fig. $4 \mathrm{~b}$ ). The general pattern is that, from 1994 to 2011, the most evident increase in $\mathrm{C}_{\mathrm{ant}}$ occurred in the upper $1000 \mathrm{dbar}$, particularly in the southern half of the section, with the $\Delta \mathrm{C}_{\text {ant }}$ increasing towards the surface. The atmosphere is the main source of $\mathrm{C}_{\mathrm{ant}}$ to the ocean; thus it follows that the waters most recently in contact with the atmosphere will show the greatest $\Delta \mathrm{C}_{\mathrm{ant}}$. Within the surface waters $(<100 \mathrm{dbar})$ of the section the $\Delta \mathrm{C}_{\text {ant }}$ gradually decreases northwards in a linear relationship with latitude $\left(R^{2}=-0.74\right)$ to a concentration of $0 \mu \mathrm{mol} \mathrm{kg}-1$ just north of the Equator $\left(\sim 5^{\circ} \mathrm{N}\right)$. Despite containing large quantities of $\mathrm{C}_{\text {ant }}$ (Fig. 4a), low $\Delta \mathrm{C}_{\text {ant }}$ values $\left(<5 \mu \mathrm{mol} \mathrm{kg}{ }^{-1}\right)$ have been previously noted in the tropical Atlantic region, to a depth of $200 \mathrm{dbar}$, similar to that observed here (Schneider et al., 2012). The same authors(Schneider et al., 2012) have suggested that greater precipitation in the Intertropical Convergence Zone can cause errors in the surface $C_{a n t}$ determinations in the tropical Atlantic, due to the related increase in Revelle factor. In the section presented here the Amazon outflow can also be seen in salinity values; thus a variation in freshwater input may also contribute to errors in the method.

The largest increase (up to $37 \mu \mathrm{mol} \mathrm{kg}^{-1}$ ) in surface waters was found in the SAZ, just south of $45^{\circ} \mathrm{S}$, in agreement with the findings of Wanninkhof et al. (2010). The steepest vertical gradient of $\Delta \mathrm{C}_{\mathrm{ant}}$ is found in the same region, at $\sim 47^{\circ} \mathrm{S}$ just north of the SAF, where over a depth range of 0-600 dbar the $\Delta C_{\text {ant }}$ decreases from 37 to $0 \mu \mathrm{mol} \mathrm{kg}{ }^{-1}$. Further north, the deepest penetration of positive $\Delta C_{\text {ant }}$ val- 

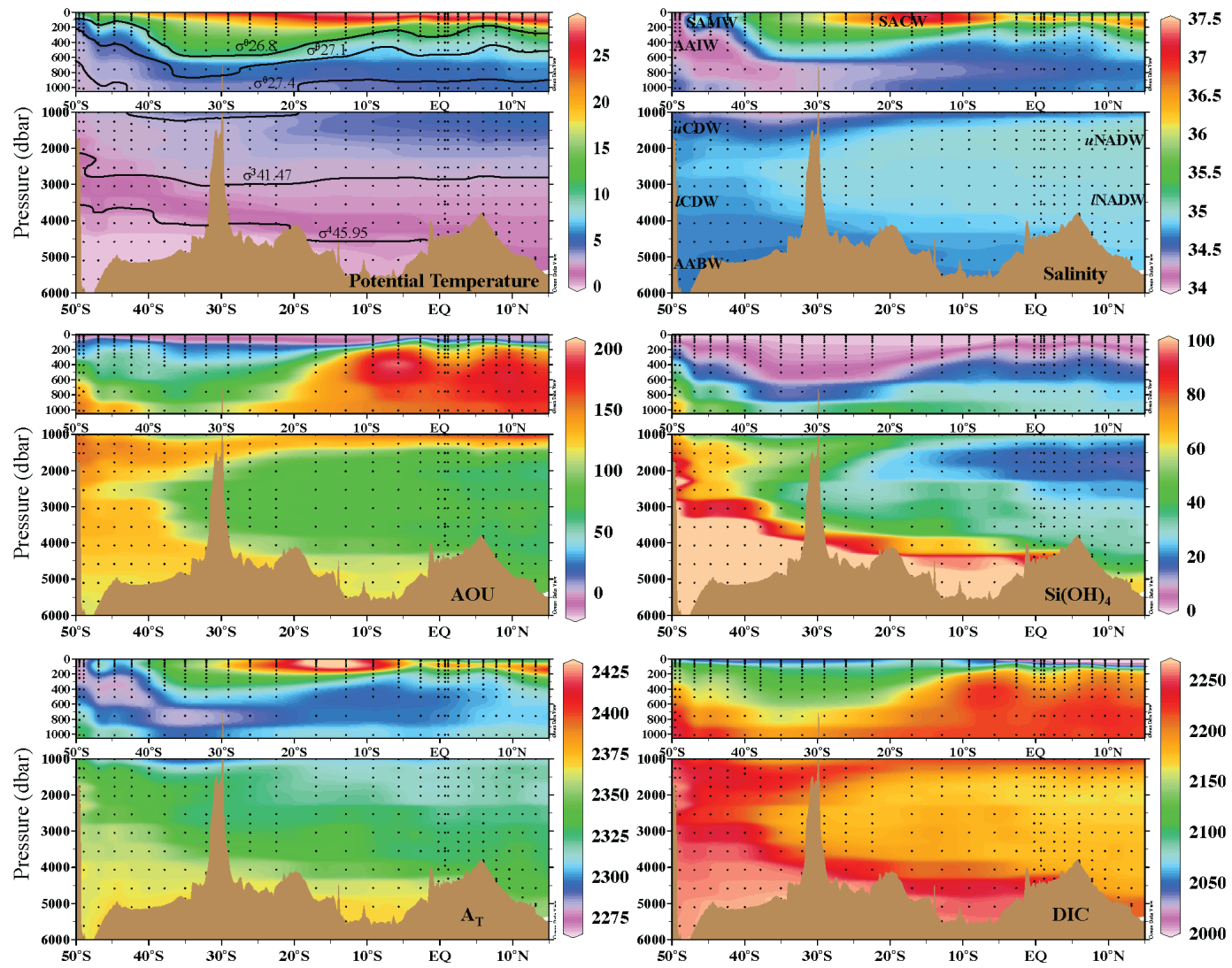

Figure 3. Section distributions of temperature $\left({ }^{\circ} \mathrm{C}\right)$, salinity, $\mathrm{AOU}\left(\mu \mathrm{mol} \mathrm{kg}{ }^{-1}\right)$, silicate $(\mu \mathrm{mol} \mathrm{kg}-1), A_{\mathrm{T}}\left(\mu \mathrm{mol} \mathrm{kg}{ }^{-1}\right)$ and DIC $\left(\mu \mathrm{mol} \mathrm{kg}{ }^{-1}\right)$ from the GEOTRACES-NL (2010/2011) data set.

Table 2. The calculated rates of increase in $\mathrm{C}_{\mathrm{ant}}$ and rates of decrease in $\mathrm{pH}$ along the section, listed per water mass. The identification criteria for each water mass are provided. Error represents $2 \sigma / \mathrm{N}^{0.5}$.

\begin{tabular}{llrrrrr}
\hline Water mass & Density range & Latitude & $\begin{array}{r}\text { Pressure } \\
(\mathrm{dbar})\end{array}$ & $\begin{array}{r}\mathrm{dC}_{\mathrm{ant}} / \mathrm{dt} \\
\left(\mu \mathrm{mol} \mathrm{kg} \mathrm{yr}^{-1}\right)\end{array}$ & $\begin{array}{r}\mathrm{dC}_{\mathrm{ant}} / \mathrm{dt}^{*} \\
\left(\mu \mathrm{mol} \mathrm{kg}^{-1} \mathrm{yr}^{-1}\right)\end{array}$ & $\begin{array}{r}\mathrm{dpH} / \mathrm{dt} \\
\left(\mathrm{yr}^{-1}\right)\end{array}$ \\
\hline SACW & $\sigma^{\theta} 20-\sigma^{\theta} 26.8$ & $23-18^{\circ} \mathrm{S}$ & $90-160$ & $0.99 \pm 0.14$ & $0.90 \pm 0.04$ & -0.0016 \\
SAMW & $\sigma^{\theta} 26.8-\sigma^{\theta} 27.1$ & $50-48^{\circ} \mathrm{S}$ & $90-160$ & $0.53 \pm 0.11$ & $0.53 \pm 0.02$ & -0.0014 \\
AAIW & $\sigma^{\theta} 27.1-\sigma^{\theta} 27.4$ & $50-48^{\circ} \mathrm{S}$ & $360-450$ & $0.36 \pm 0.06$ & $0.36 \pm 0.06$ & -0.0010 \\
$u$ CDW & $\sigma^{\theta} 27.4-\sigma^{3} 41.47$ & $50-49^{\circ} \mathrm{S}$ & $1400-1800$ & $0.33 \pm 0.07$ & $0.16 \pm 0.04$ & -0.0010 \\
$u$ NADW & $\sigma^{\theta} 27.4-\sigma^{3} 41.47$ & $10-15^{\circ} \mathrm{N}$ & $1600-1800$ & $0.20 \pm 0.03$ & $0.16 \pm 0.04$ & -0.0005 \\
$l$ CDW & $\sigma^{3} 41.47-\sigma^{4} 45.9$ & $50-48^{\circ} \mathrm{S}$ & $3250-3750$ & $0 \pm 0.06$ & $0.08 \pm 0.04$ & 0.0000 \\
$l$ NADW & $\sigma^{3} 41.47-\sigma^{4} 45.9$ & $10-15^{\circ} \mathrm{N}$ & $3000-3500$ & $0 \pm 0.02$ & $0.08 \pm 0.04$ & 0.0000 \\
\hline
\end{tabular}

* Values from Ríos et al. (2012).

ues in the southern half of the section is found at $1200 \mathrm{dbar}$ in the SubTropical Zone (STZ), between 25 and $40^{\circ} \mathrm{S}$. The $\Delta \mathrm{C}_{\text {ant }}$ zero-contour shoals southward of $35^{\circ} \mathrm{S}$ to $\sim 600 \mathrm{dbar}$ at $50^{\circ} \mathrm{S}$, coinciding with the lower limits of AAIW, as has been noted in other ocean basins (Sabine et al., 2004). In the northern half of the section, the deepest limit of $\Delta \mathrm{C}_{\mathrm{ant}}$ penetration in AAIW reaches a depth of $\sim 700 \mathrm{dbar}$ at $15^{\circ} \mathrm{S}$, and north of the Equator the AAIW signal becomes distorted as it mixes with NADW. The NADW shows near-zero concen- trations of $\Delta \mathrm{C}_{\mathrm{ant}}$ throughout its extent, with the exception of the $u \mathrm{NADW}$ in the equatorial region, which shows $\Delta \mathrm{C}_{\mathrm{ant}}$ values up to $5 \mu \mathrm{mol} \mathrm{kg}{ }^{-1}$. In $l \mathrm{NADW}$ and the other deep and bottom waters (AABW, $l \mathrm{CDW}$ ), $\Delta \mathrm{C}_{\mathrm{ant}}$ shows no change or a tendency towards negative values.

To estimate the rate of increase in $\mathrm{C}_{\mathrm{ant}}$ in each water mass, we identified their respective cores (Fig. 3b) using the water mass descriptions given in Mémery et al. (2000) and Ríos et al. (2012) and averaged their values 

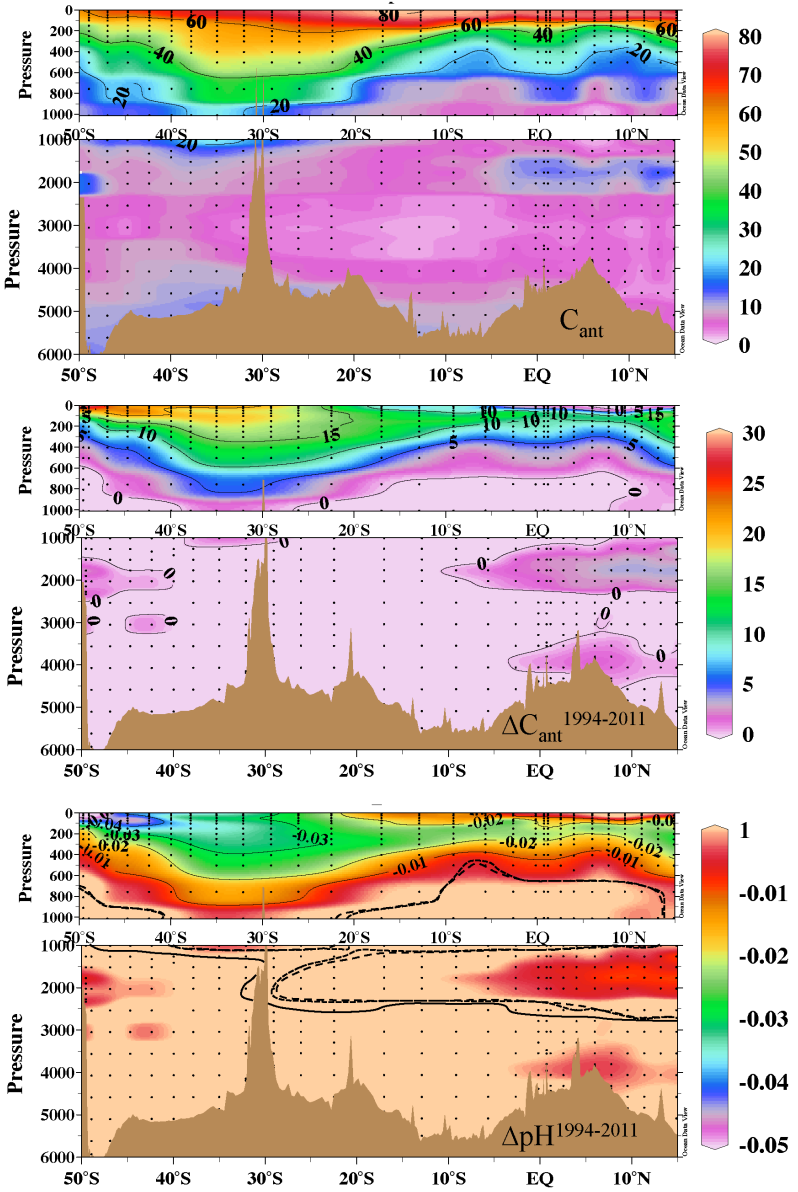

Figure 4. Distribution of $\mathrm{C}_{\mathrm{ant}}\left(\mu \mathrm{mol} \mathrm{kg} \mathrm{kg}^{-1}\right)$ calculated using the $\phi \mathrm{C}_{\mathrm{T}}^{0}$ method with the GEOTRACES-NL (2010/2011) data set (top); distribution of $\Delta \mathrm{C}_{\mathrm{ant}}^{1994-2011}$ ( $\mu \mathrm{mol} \mathrm{kg} \mathrm{kg}^{-1}$ ), calculated using the eMLR approach (middle); and the distribution of the $\Delta \mathrm{pH}^{1994-2011}$ associated with $\Delta \mathrm{C}_{\text {ant }}^{1994-2011}$ (bottom). The aragonite saturation horizon $(\Omega \mathrm{Ar})$ is marked for pre-industrial times (solid line), 1994 (dashed line) and 2011 (dotted line).

of $\Delta \mathrm{C}_{\mathrm{ant}}$. Assuming a constant yearly increase, we then divided this total increase by 17 to obtain the rate of yearly increase in $\mathrm{C}_{\mathrm{ant}}$ over the period 1994 to 2011. The calculated values are shown in Table 2 with those of Ríos et al. (2012) for comparison. The highest rates of increase were found in SACW and SAMW with $\mathrm{C}_{\text {ant }}$ increase rates of $0.99 \pm 0.14$ and $0.53 \pm 0.11 \mu \mathrm{mol} \mathrm{kg}{ }^{-1} \mathrm{yr}^{-1}$, respectively. The latter value shows good consistency with that calculated by Ríos et al. (2012) $\left(0.53 \pm 0.02 \mu \mathrm{mol} \mathrm{kg}{ }^{-1} \mathrm{yr}^{-1}\right)$. However, there is a notable difference of $0.09 \mu \mathrm{mol} \mathrm{kg}^{-1} \mathrm{yr}^{-1}$ between the increase for SACW calculated here and that of $0.90 \pm 0.04 \mu \mathrm{mol} \mathrm{kg} \mathrm{yr}^{-1}$ (Ríos et al., 2012). As this is a surface water mass, and our study utilized data collected 6 years after those used for comparison in Ríos et al. (2012), we corrected the $\Delta C_{\text {ant }}$ accordingly. Assuming equilibration between the atmosphere and ocean, we corrected our $\Delta \mathrm{C}_{\mathrm{ant}}$ value for the additional DIC increase caused solely by atmospheric increases over the last 6 years. The resulting calculated $C_{\text {ant }}^{1994-2005}$ increase rate was $0.92 \pm 0.14 \mu \mathrm{mol} \mathrm{kg}^{-1} \mathrm{yr}^{-1}$, making our result consistent with the previous estimate. As such, we attribute the difference in calculated $\Delta \mathrm{C}_{\text {ant }}$ increase rates in SACW to the increase in DIC driven by higher atmospheric $p \mathrm{CO}_{2}$ concentrations in 2010/2011.

Despite the similarities in formation history between SAMW and AAIW, the latter shows a much lower $\mathrm{C}_{\text {ant }}$ increase rate of $0.37 \pm 0.06 \mu \mathrm{mol} \mathrm{kg}^{-1} \mathrm{yr}^{-1}$. The discrepancy between the $\mathrm{C}_{\text {ant }}$ increase rates in these two water masses is in line with the differences in air-sea $\mathrm{CO}_{2}$ flux in the region (McNeil et al., 2007). In the SAZ a combination of biological production and temperature variability leads to a large seasonal signal of $p \mathrm{CO}_{2}$. The SAMW is formed in the SAZ, where there is high biological production in spring and summer and wintertime cooling of surface waters. The wintertime cooling effect on the solubility of $\mathrm{CO}_{2}$ is sufficient to counteract the increase in DIC from mixing, resulting in a strong year-round $\mathrm{CO}_{2}$ sink. South of the SAF, where AAIW is formed, similar processes operate; however, the biological production is lower, and convective wintertime mixing brings up high-DIC waters, thus reducing the $\mathrm{CO}_{2}$ sink (McNeil et al., 2007). It has also been shown that the formation rate of AAIW in the Indian Ocean is less than that of SAMW, which facilitates more efficient sequestration of $\mathrm{C}_{\mathrm{ant}}$ by the latter (Hartin et al., 2011).

Modest increase rates of $0.33 \pm 0.07$ and $0.20 \pm 0.03 \mu \mathrm{mol} \mathrm{kg}^{-1} \mathrm{yr}^{-1}$ were calculated for $u \mathrm{CDW}$ and $u \mathrm{NADW}$, respectively. Both these water masses have been fairly recently ventilated, allowing modest increases in $\Delta \mathrm{C}_{\mathrm{ant}}$. The increase rate for $u \mathrm{NADW}$ is in line with values found by Perez et al. (2010). Due to the very low $\Delta \mathrm{C}_{\mathrm{ant}}$ values found in $l \mathrm{NADW}$ and $l \mathrm{CDW}$, their respective increase rates are not significant and are not discussed further. In contrast to our calculated $\Delta \mathrm{C}_{\mathrm{ant}}$, a number of studies have found increasing concentrations of $\mathrm{C}_{\mathrm{ant}}$ in $\mathrm{AABW}$ (Murata et al., 2008; Vázquez-Rodríguez et al., 2009a; Brown et al., 2010). However, it has been noted previously that it is absent in eMLR analyses (Wanninkhof et al., 2010). The distributions of $\mathrm{C}_{\mathrm{ant}}$ in $\mathrm{AABW}$ presented in Vázquez-Rodríguez et al. (2009a) also indicate that $\mathrm{C}_{\mathrm{ant}}$ concentrations have not yet spread further north than $50^{\circ} \mathrm{S}$, potentially explaining its absence in our analysis.

\subsection{Associated changes in $\mathbf{p H}$}

Assuming no changes in $A_{\mathrm{T}}$ between the WOCE '94 A17 and GEOTRACES-NL (2010/2011) occupations, we use the $\Delta \mathrm{C}_{\mathrm{ant}}$ calculated by eMLR and the measured $A_{\mathrm{T}}$ during GEOTRACES-NL (2010/2011) to calculate the anthropogenically driven change in $\mathrm{pH}$ from 1994 to 2011 $\left(\Delta \mathrm{pH}^{1994-2011}\right)$. From the application of the $\phi \mathrm{C}_{\mathrm{T}}^{0}$ method of anthropogenic carbon determination (Sect. 2.3.2) to the 
WOCE '94 A17 data set, we obtain the total $\mathrm{C}_{\text {ant }}$ signal from pre-industrial times to 1994 (Fig. 4a). The $\mathrm{C}_{\text {ant }}$ value allows the calculation of the decline in $\mathrm{pH}$, which has been caused by increasing $\mathrm{C}_{\mathrm{ant}}$ during this time period (from preindustrial times to 1994: $\left.\Delta \mathrm{pH}^{1994}\right)$. The average surface ( $<250 \mathrm{dbar}) \Delta \mathrm{pH}^{1994}$ across the section was -0.08 , which is just under the predicted general surface ocean decrease of 0.1 (Orr et al., 2005). The ocean interior experienced relatively small $\Delta \mathrm{pH}^{1994}$; however, the change was accompanied by a significant shoaling of the aragonite saturation horizon, most notably in the southern half of the section (Fig. 4c). From pre-industrial times to 1994 , south of the $\mathrm{SAF}$, at $\sim 49^{\circ} \mathrm{S}$, the aragonite saturation horizon rose by $\sim 250 \mathrm{~m}$, whereas further north, at $25^{\circ} \mathrm{S}$, it rose just $200 \mathrm{~m}$. The change was almost imperceptible north of the Equator. From 1994 to 2011, $\Delta \mathrm{pH}^{1994-2011}$, there is a further decline of 0.03 units, making the total surface $\Delta \mathrm{pH}^{2011}-0.11$ units since pre-industrial times. Thus, of the total decrease since pre-industrial times to the present day, $27 \%$ occurred within the past 17 years. However, we can detect no notable change to the aragonite saturation horizon over the past 17 years (Fig. 4c). Historically, the uptake of $\mathrm{C}_{\mathrm{ant}}$ by the surface ocean was relatively gradual, which allowed it to be well distributed throughout the water column. In contrast, the effects of the more recent, steeply increasing anthropogenic acidification have not yet significantly penetrated into the deeper ocean.

The distribution of $\Delta \mathrm{pH}^{1994-2011}$ across the section broadly follows the $\mathrm{C}_{\mathrm{ant}}$ increases (compare Fig. 4b, c), as expected under the assumption of constant $A_{\mathrm{T}}$. By assuming a constant decrease over the 17 years, the yearly acidification rates are calculated from $\Delta \mathrm{pH}^{1994-2011}$ and identified for each water mass core, as done for the yearly $\mathrm{C}_{\mathrm{ant}}$ increases (Table 2). The highest rates of acidification were found in the surface waters, where we also observe the greatest rates of $\mathrm{C}_{\mathrm{ant}}$ increase, with SACW showing a rate of $\mathrm{pH}$ decrease of $0.0016 \mathrm{yr}^{-1}$. The latter value is in line with that calculated for the same water mass on the eastern side of the North Atlantic Ocean at the ESTOC site $\left(0.0017 \mathrm{yr}^{-1}\right)$ for the period 1995 to 2004 (Santana-Casiano et al., 2007; GonzálezDávila et al., 2011). The SAMW demonstrates the next greatest rate of decline of $0.0014 \mathrm{yr}^{-1}$, followed by AAIW and $u \mathrm{CDW}$ both showing acidification rates of $0.001 \mathrm{yr}^{-1}$, which are comparable with values from other recently ventilated water masses in the North Atlantic: acidification rates of 0.0019 and $0.0012 \mathrm{yr}^{-1}$ have been reported for SAIW and SPMW, respectively (Vázquez-Rodríguez et al., 2012). The lowest non-zero acidification rate of $0.0005 \mathrm{yr}^{-1}$ is found in $u$ NADW.

\subsection{Buffering capacity}

The continuing uptake of atmospheric $\mathrm{CO}_{2}$ gradually depletes the naturally available carbonate ion in the surface ocean, thereby decreasing the capacity to "buffer" further $\mathrm{CO}_{2}$ uptake and leading to the gradual acidification of the seawater. The extent to which the $\mathrm{pH}$ is affected by the increase in DIC is dependent upon several properties, including temperature, pressure and $A_{\mathrm{T}}$, which together determine the buffering capacity of the water. As DIC increases, assuming no other changes take place, the buffering capacity of the water is reduced as $\left[\mathrm{CO}_{3}^{2-}\right]$ decreases and $\left[\mathrm{CO}_{2}\right]$ increases. The $A_{\mathrm{T}}$ is not altered by the flux of atmospheric $\mathrm{CO}_{2}$ into the ocean. However, $A_{\mathrm{T}}$ is affected by biological processes, notably the dissolution and formation of calcium carbonate, with dissolution dominating in deep waters and formation playing a more important role in the surface. Table 2 quantifies the extent to which the calculated $\Delta \mathrm{C}_{\mathrm{ant}}$ has impacted $\mathrm{pH}$ in the water masses of the southwestern Atlantic Ocean. Examination of this table clearly shows that the rate of acidification per $\mu \mathrm{mol} \mathrm{kg}-1$ of DIC is not equal between water masses. The SAMW, a relatively fresh, low-alkalinity water mass, has an acidification rate of $-0.0014 \mathrm{yr}^{-1}$, which is $88 \%$ of that of SACW, a warmer, more saline water mass. However, the $\mathrm{C}_{\mathrm{ant}}$ increase rate of SAMW is only $54 \%$ that of SACW. The AAIW shows the same rate of acidification as $u \mathrm{CDW}$; however, the increase in $\mathrm{C}_{\text {ant }}$ in $u \mathrm{CDW}$ is $10 \%$ lower than that of AAIW. These differences can be attributed to the varying buffering capacities of the water masses.

The distributions of the Revelle factor and the sensitivities of $\left[\mathrm{H}^{+}\right](\beta \mathrm{DIC}),\left[\mathrm{CO}_{2}\right](\gamma \mathrm{DIC})$ and $\Omega_{\mathrm{CaCO}_{3}}(\omega \mathrm{DIC})$ to changes in DIC for the southwestern Atlantic are shown in Fig. 5 and given per water mass in Table 3 . The highest buffer factors, which indicate the greatest sensitivities to increasing DIC (denoted by low values in Fig. 5b, c, and high values in d) were generally found in the deep waters. That is to say that, for a given increase in DIC, these waters will show large resultant changes in $\left[\mathrm{H}^{+}\right],\left[\mathrm{CO}_{2}\right]$ and $\left[\mathrm{CO}_{3}^{2-}\right]$, or aragonite and calcite saturation $\left(\Omega_{\mathrm{Ar}}, \Omega_{\mathrm{Ca}}\right)$. Both $u \mathrm{CDW}$ and $l \mathrm{CDW}$ show very similar behaviour - as expected from their similar history - however, interestingly, there is a notable difference between the buffering capacities of the two limbs of NADW. The difference is most noticeable in $\omega$ DIC, likely caused by the slightly higher $A_{\mathrm{T}} /$ DIC ratio in $l$ NADW. A lower $\beta$ DIC in $u$ NADW denotes a greater sensitivity to acidification in response to increasing DIC concentrations. More rapid acidification in $u$ NADW compared to $l$ NADW has been observed by Vázquez-Rodríguez et al. (2012) and attributed to mixing with Labrador Sea Water (LSW), which exhibits a strong decreasing $\mathrm{pH}$ trend with time. The lower $\mathrm{pH}$ of LSW and its contribution to $u$ NADW could account for the reduced buffering capacity calculated in this water mass in the southwestern Atlantic Ocean.

The lowest Revelle factor and highest $\beta$ DIC values are found in SACW, closely followed by SAMW, which despite containing large concentrations of $\mathrm{C}_{\mathrm{ant}}$, both have relatively low concentrations of DIC compared to the other water masses. The SACW and SAMW also have higher concentrations of $A_{\mathrm{T}}$ giving them greater buffering capacity. The three water masses with the greatest response in $\mathrm{pH}$ relative to $\Delta \mathrm{C}_{\text {ant }}$ were AAIW, $u \mathrm{CDW}$ and $l \mathrm{CDW}$, with $\beta \mathrm{DIC}$ 
Table 3. The average water mass values of salinity and potential temperature, with accompanying average buffering capacity values $(\gamma$ DIC, $\beta$ DIC, $\omega$ DIC and Revelle factor) calculated using the GEOTRACES-NL (2010/2011) data set. Water masses are determined using the same criteria as given in Table 2 .

\begin{tabular}{lrrrrrr}
\hline Water mass & Salinity & $\begin{array}{r}\text { Theta } \\
\left({ }^{\circ} \mathrm{C}\right)\end{array}$ & $\begin{array}{r}\gamma \text { DIC } \\
\left(\mathrm{mmol} \mathrm{kg}^{-1}\right)\end{array}$ & $\begin{array}{r}\beta \text { DIC } \\
\left(\mathrm{mmol} \mathrm{kg}^{-1}\right)\end{array}$ & $\begin{array}{r}\omega \text { DIC } \\
\left(\mathrm{mmol} \mathrm{kg}^{-1}\right)\end{array}$ & Revelle factor \\
\hline SACW & 36.854 & 22.693 & 0.211 & 0.256 & -0.327 & 10.02 \\
SAMW & 34.021 & 4.4218 & 0.144 & 0.161 & -0.181 & 14.83 \\
AAIW & 34.222 & 2.8567 & 0.136 & 0.149 & -0.165 & 16.02 \\
$u$ CDW & 34.682 & 1.9528 & 0.132 & 0.143 & -0.156 & 17.14 \\
$u$ NADW & 34.987 & 3.8578 & 0.132 & 0.168 & -0.191 & 14.40 \\
\hline
\end{tabular}
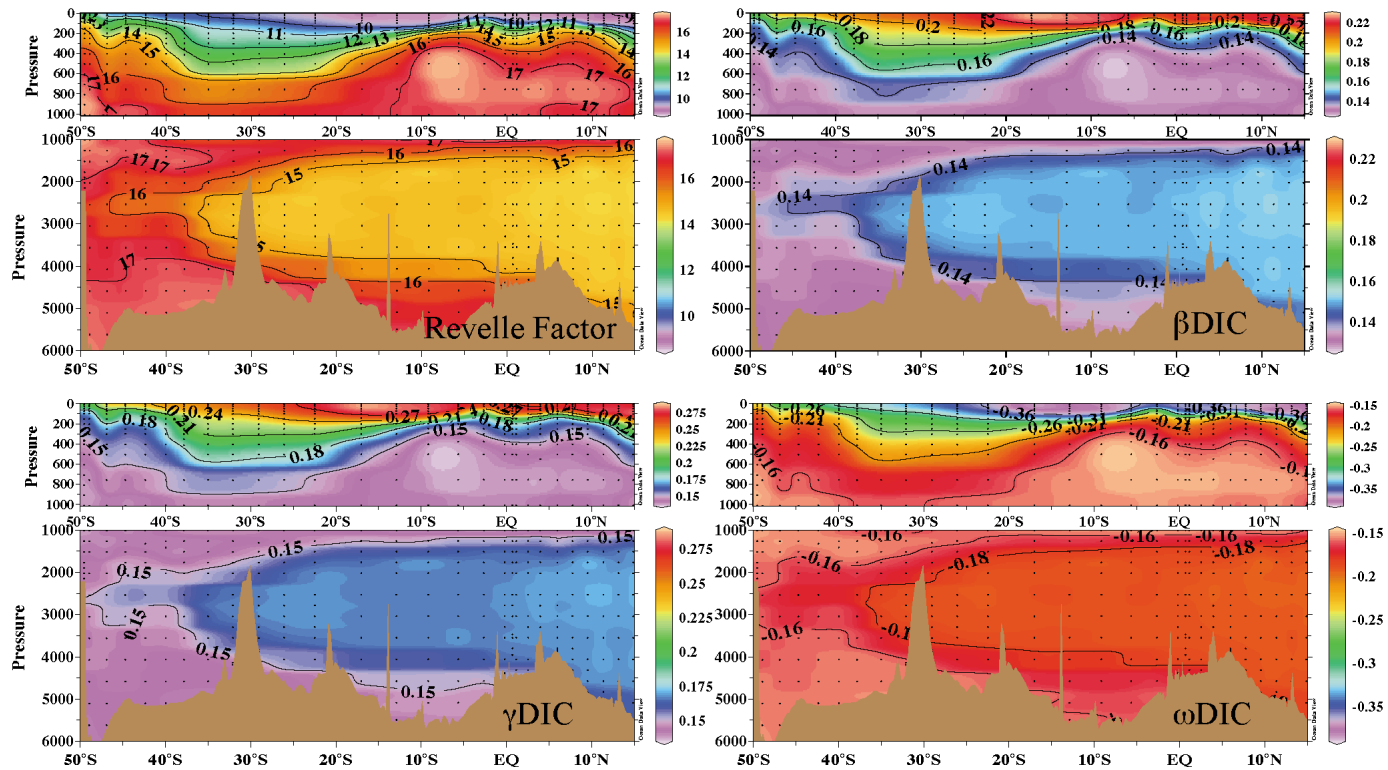

Figure 5. Distribution of the Revelle factor across the section (top left) and the three buffering factors relating to DIC: $\beta$ DIC (top right), $\gamma$ DIC (bottom left) and $\omega$ DIC (bottom right). The latter three are all given in $\mathrm{mmol} \mathrm{kg}^{-1}$.

values of $0.148,0.141$ and $0.143 \mathrm{mmol} \mathrm{kg}^{-1}$, respectively. These water masses show the highest DIC / $A_{\mathrm{T}}$ ratios along the section as they all originate in the Southern Ocean (SO), where upwelling brings deep waters rich in $\left[\mathrm{CO}_{2}(\mathrm{aq})\right]$ and low in $\left[\mathrm{CO}_{3}^{2-}\right]$ to the surface. In addition, these waters have slightly lower salinities and thus lower borate concentrations, which further diminish their buffering capacity, also reflected in the high Revelle factors (Fig. 5a). For the same DIC value, the buffering capacity of AAIW is substantially lower than that of $u \mathrm{CDW}$ stemming from the low $A_{\mathrm{T}}$ of AAIW, which is also reflected in the high $\omega$ DIC values. With the current calculated rate of increase in $\mathrm{C}_{\mathrm{ant}}$, aragonite will become undersaturated in AAIW around the year 2100, when DIC concentrations reach $2208 \mu \mathrm{mol} \mathrm{kg}{ }^{-1}$. This could happen even sooner, as wintertime, storm-driven upwelling entrainment of deep waters into the surface in the SO is predicted to cause seasonal aragonite undersaturation in the region as soon as 2030, when atmospheric $\mathrm{CO}_{2}$ levels reach $\sim 450 \mathrm{ppm}$ (McNeil and Matear, 2008).

\subsection{Continued $\mathrm{C}_{\text {ant }}$ increase}

The buffering capacity of each water mass will be reduced by increasing the DIC concentrations. To investigate how the buffering capacities of the different water masses in this section have changed over time, and how they will continue to change, the DIC buffer factors of each water mass were calculated and plotted against DIC concentration (Fig. 6). Due to the large relative error of the calculated $\Delta \mathrm{C}_{\mathrm{ant}}$ increases in the deeper waters, these were not included. The high rate of uptake of $\mathrm{C}_{\text {ant }}$ by SACW means that this water mass has seen the largest decrease in buffering capacity since preindustrial times. The $\beta$ DIC value has decreased from 0.281 to $0.247 \mathrm{mmol} \mathrm{kg}^{-1}$ and $\Omega_{\mathrm{Ar}}$ has decreased from 4.1 to 3.3 . In contrast, $u \mathrm{CDW}$ has shown relatively little change due to the low values of $\mathrm{C}_{\mathrm{ant}}$. However, extrapolating our calculated $\mathrm{C}_{\text {ant }}$ rates of increase, we predict a $33 \mu \mathrm{mol} \mathrm{kg}{ }^{-1}$ increase in this water mass over the next century, which will result in a significant reduction in buffering and a $\mathrm{pH}$ decrease of 


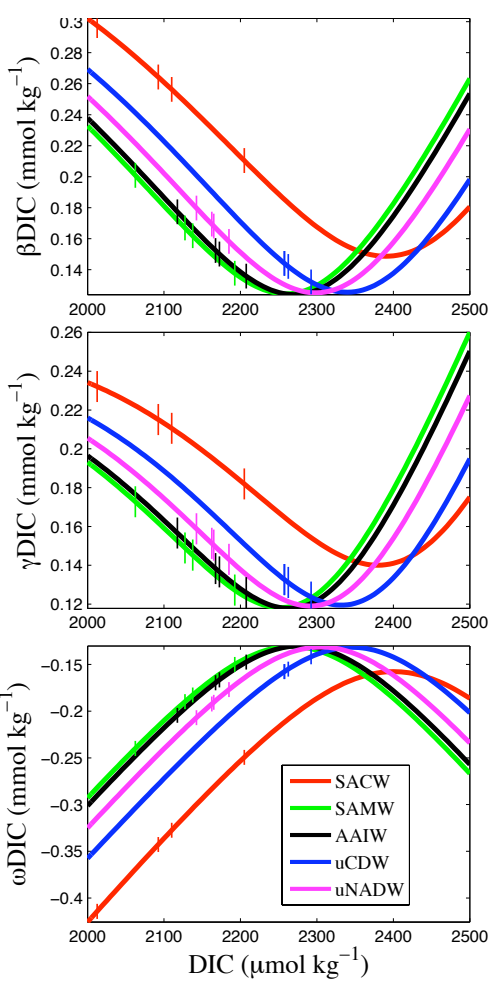

Figure 6. The buffer factors $\beta$ DIC (top), $\gamma$ DIC (middle) and $\omega$ DIC (bottom) of each water mass over a range of DIC concentrations. The vertical lines denote the DIC concentration in pre-industrial times, 1994 and 2011 and the projected concentration in 2110.

-0.102 . The buffering capacities of SAMW and AAIW follow a similar pattern to each other; however, SAMW contains a greater proportion of subtropical water than AAIW, and thus it maintains a slightly higher buffering capacity than AAIW. Both AAIW and $u$ CDW will see a similar increase in $\mathrm{C}_{\text {ant }}$ over the next century ( 37 and $33 \mu \mathrm{mol} \mathrm{kg}{ }^{-1}$, respectively); however, the decline in $\Omega_{\mathrm{Ar}}$ will be 1.6 times greater in AAIW, due to higher $\omega$ DIC values. The SAMW will see approximately $54 \%$ of the increase in $\mathrm{C}_{\text {ant }}$ that $\mathrm{SACW}$ will experience; however, it will undergo $84 \%$ of the associated $\mathrm{pH}$ decline. These extrapolated predictions highlight the vulnerability of SAMW and AAIW to increasing $\mathrm{C}_{\mathrm{ant}}$, as also noted by Gonzalez-Davila et al. (2011).

The observed pattern of $\Delta C_{a n t}$ in the southwestern Atlantic clearly identifies the SAZ as the most effective entry point of $\mathrm{C}_{\mathrm{ant}}$ into the ocean. In addition, the buffering factors of Egleston et al. (2010) explicitly show that by, the end of this century, the two dominant water masses in this area (SAMW and AAIW) will be the most sensitive to further $\mathrm{C}_{\mathrm{ant}}$ increases. Whilst it is clear that this will accelerate the rate of acidification in these water masses, it is unclear how it will affect the $\mathrm{CO}_{2}$ uptake in the SAZ. Assuming no changes to primary production, the increased sensitivity of SAMW to DIC changes will lead to much greater seasonal variability in the carbonate system of this water mass between the pro- ductive and non-productive period. The biological uptake of DIC in the SAZ in austral spring and summer would lead to a more dramatic decrease in surface water $p \mathrm{CO}_{2}$, allowing a greater air-sea $p \mathrm{CO}_{2}$ flux. Conversely, the acidification and decline in $\Omega_{\mathrm{Ar}}$ may be detrimental to calcifying organisms in the area, as observed in the Southern Ocean (Bednarsek et al., 2012), thus limiting export via the biological pump.

The water masses SAMW and AAIW both risk further reduction in their buffering capacities by long-term variability to their physical properties. On decadal timescales a freshening of AAIW has been observed in the Pacific and Indian sectors of the Southern Ocean (Wong et al., 1999). Decadal variability has also been noted in temperature, salinity and biogeochemical parameters of SAMW (Bindoff et al., 2007; Alvarez et al., 2011), which could further diminish or enhance the buffering capacity of this water mass and thus the $\mathrm{C}_{\text {ant }}{ }^{-}$ driven acidification. Variations on decadal timescales have been related to the Southern Annular Mode, the dominant climate forcing over the region (Lovenduski et al., 2007; Álvarez et al., 2011). Similarly in the North Atlantic, the North Atlantic Oscillation exerts a degree of control over the carbonate system variables and $\mathrm{C}_{\mathrm{ant}}$ uptake (Santana-Casiano et al., 2007; Pérez et al., 2010). Such external controls will cause irregular $C_{a n t}$ uptake over time, as was observed by Brown et al. (2010), making it difficult to accurately predict future $\mathrm{C}_{\text {ant }}$ uptake and associated changes in the buffering capacity.

\section{Conclusions}

The continuing uptake of $\mathrm{C}_{\mathrm{ant}}$ in the southwestern Atlantic has been assessed through application of eMLR to two data sets collected in 1994 and 2011. The distribution of $\Delta C_{\text {ant }}$ is comparable with previous studies of $\mathrm{C}_{\mathrm{ant}}$ accumulation in the region (Ríos et al., 2010). The largest increases are found in the SAZ, just north of the $\mathrm{SAF}$, a previously identified substantial $\mathrm{CO}_{2}$ sink (Metzl et al., 1999). The SACW $\left(0.99 \pm 0.14 \mu \mathrm{mol} \mathrm{kg}^{-1} \mathrm{yr}^{-1}\right)$, SAMW $\quad\left(0.53 \pm 0.11 \mu \mathrm{mol} \mathrm{kg}^{-1} \mathrm{yr}^{-1}\right)$ and AAIW $\left(0.36 \pm 0.06 \mu \mathrm{mol} \mathrm{kg} \mathrm{gr}^{-1}\right)$ are responsible for the greatest $\mathrm{C}_{\mathrm{ant}}$ uptake, consistent with earlier studies showing them to be an effective pathway of $\mathrm{C}_{\mathrm{ant}}$ into the ocean interior (Álvarez et al., 2009). The lower extent of AAIW demarks the greatest depth of penetration of $\mathrm{C}_{\mathrm{ant}}$ into the ocean in the past 17 years, indicating that future uptake will, similarly, be largely concentrated within the surface $1000 \mathrm{~m}$.

The increase in $\mathrm{C}_{\mathrm{ant}}$ in the southwestern Atlantic has led to acidification of water masses. The calculated $\mathrm{C}_{\mathrm{ant}}$-driven acidification is greatest in SACW, where a current rate of $\mathrm{pH}$ decline of $0.0016 \mathrm{yr}^{-1}$ is found. However, the acidification response per $\mu \mathrm{mol} \mathrm{kg}{ }^{-1}$ increase in DIC is greatest in the intermediate and mode waters. We identify SAMW as the water mass with the greatest risk of rapid acidification in the future, due to a combination of its high $\mathrm{C}_{\mathrm{ant}}$ uptake and its 
limited buffering capacity. AAIW, on the other hand, is more at risk of aragonite undersaturation due its low $A_{\mathrm{T}}$ values and resultant high $\omega$ DIC values. Continued increase in $\mathrm{C}_{\mathrm{ant}}$ at the current rate calculated will lead to aragonite undersaturation in the core of AAIW around the year 2100.

Acknowledgements. We thank the captains and crews of RV Pelagia and RRS James Cook. The Earth and Life Sciences division (ALW) of the Netherlands Organisation for Scientific Research (NWO) supported this research under project number 817.01.004. The research leading to these results was supported through the EU FP7 project CARBOCHANGE "Changes in carbon uptake and emissions by oceans in a changing climate", which received funding from the European Commission's Seventh Framework Programme under agreement no. 264879. We also thank M. Álvarez and an additional, anonymous referee for their helpful comments and suggestions.

Edited by: G. Herndl

\section{References}

Álvarez, M., Lo Monaco, C., Tanhua, T., Yool, A., Oschlies, A., Bullister, J. L., Goyet, C., Metzl, N., Touratier, F., McDonagh, E., and Bryden, H. L.: Estimating the storage of anthropogenic carbon in the subtropical Indian Ocean: a comparison of five different approaches, Biogeosciences, 6, 681-703, doi:10.5194/bg6-681-2009, 2009.

Álvarez, M., Tanhua, T., Brix, H., Lo Monaco, C., Metzl, N., McDonagh, E. L., and Bryden H. L.: Decadal biogeochemical changes in the subtropical Indian Ocean associated with Subantarctic Mode Water, J. Geophys. Res., 116, C09016, doi:10.1029/2010JC006475, 2011.

Álvarez, M., Sanleón-Bartolomé, H., Tanhua, T., Mintrop, L., Luchetta, A., Cantoni, C., Schroeder, K., and Civitarese, G.: The $\mathrm{CO} 2$ system in the Mediterranean Sea: a basin wide perspective, Ocean Sci., 10, 69-92, doi:10.5194/os-10-69-2014, 2014.

Bednarsek, N., Tarling, G. A., Bakker, D. C. E., Fielding, S., Jones, E. M., Venables, H. J., Ward, P., Kuzirian, A., Lézé, B., Feely, R. A., and Murphy, E. J.: Extensive dissolution of live pteropods in the Southern Ocean, Nat. Geosci., 5, 881-885, doi:10.1038/NGEO1635, 2012.

Bindoff, N. L., Willebrand, J., Artale, V., Cazenave, A., Gregory, J., Gulev, S., Hanawa, K., Le Quéré, C., Levitus, S., Nojiri, Y., Shum, C. K., Talley, L. D., and Unnikrishnan, A.: Observations: Oceanic Climate Change and Sea Level, in: Climate Change 2007: The Physical Science Basis. Contribution of Working Group I to the Fourth Assessment Report of the Intergovernmental Panel on Climate Change, edited by: Solomon, S., Qin, D., Manning, M., Chen, Z., Marquis, M., Averyt, K. B., Tignor, M., and Miller, H. L., Cambridge University Press, Cambridge, United Kingdom and New York, NY, USA, 385-432, 2007.

Brewer, P. G.: Direct observation of the oceanic $\mathrm{CO}_{2}$ increase, Geophys. Res. Lett., 5, 997-1000, 1978.

Brown, P. J., Bakker, D. C. E., Schuster, U., and Watson, A. J.: Anthropogenic carbon accumulation in the sub- tropical North Atlantic, J. Geophys. Res., 115, C04016, doi:10.1029/2008JC005043, 2010.

CARINA Group: Carbon in the Atlantic Ocean Region - the CARINA project: Results and Data, Version 1.0., Carbon Dioxide Information Analysis Center, Oak Ridge National Laboratory, U.S. Department of Energy, Oak Ridge, Tennessee. doi:10.3334/CDIAC/otg.CARINA.ATL.V1.0, 2009.

Dickson, A. G.: Standard potential of the reaction: $\mathrm{AgCl}(\mathrm{s})+1 / 2 \mathrm{H}_{2}(\mathrm{~g})=\mathrm{Ag}(\mathrm{s})+\mathrm{HCl}(\mathrm{aq})$, and the standard acidity constant of the ion $\mathrm{HSO}_{4}^{-}$in synthetic seawater from 273.15 to 318.15 K, J. Chem. Thermodyn., 22, 113-127, 1990.

Dickson, A. G. and Millero, F. J.: A comparison of the equilibrium constants for the dissociation of carbonic acid in seawater media, Deep Sea Res., 34, 1733-1743, 1987.

Dickson, A. G., Sabine, C. L., and Christian, J. R. (Eds.): Guide to best practices for ocean $\mathrm{CO}_{2}$ measurements, PICES Special Publications 3, 191 pp., doi:10.1029/2006JC004051, 2007.

Egleston, E. S., Sabine, C. L., and Morel, M.: Revelle revisited: Buffer factors that quantify the reponse of ocean chemistry to changes in DIC and alkalinity, Global Biogeochem. Cy., 24 GB1002, doi:10.1029/2008GB003407, 2010.

Friis, K., Körtzinger, A., Patsch, J., and Wallace, D. W. R.: On the temporal increase of anthropogenic $\mathrm{CO}_{2}$ in the subpolar North Atlantic, Deep-Sea Res. Pt. I, 52, 681-698, doi:10.1016/j.dsr.2004.11.017, 2005.

González-Dávila, M., Santana-Casiano, J. M., Fine, R. A., Happell, J., Delille, B., and Speich, S.: Carbonate system in the water masses of the Southeast Atlantic sector of the Southern Ocean during February and March 2008, Biogeosciences, 8, 14011413, doi:10.5194/bg-8-1401-2011, 2011.

Grasshof, K., Ehrhardt, M., and Kremling, K.: Methods of seawater analysis, Verlag Chemie GmbH, Weinheim, 125-188, 1983.

Gruber, N., Sarmiento, J. L., and Stocker, T. F.: An improved method for detecting anthropogenic $\mathrm{CO}_{2}$ in the oceans, Global Biogeochem. Cy., 10, 809-837, 1996.

Hartin, C. A., Fine, R. A., Sloyan, B. M., Talley, L. D., Chereskin, T. K., and Happell, J.: Formation rates of Subantarctic mode water and Antarctic intermediate water within the South Pacific, DeepSea Res. Pt. I, 158, 524-534, 2011.

Hauck, J., Hoppema, M., Bellerby, R. G. J., Völker, C., and WolfGladrow, D.: Data-based estimation of anthropogenic carbon and acidification in the Weddell Sea on a decadal timescale, J. Geophys. Res., 115, C03004, doi:10.1029/2009JC005479, 2010.

Johnson, K. M., Sieburth, J. M., Williams, P. J., and Brändström, L.: Coulometric total carbon dioxide analysis for marine studies: Automation and calibration, Mar. Chem., 21, 117-133, 1987.

Karstensen, J. and Quadfasel, D.: Water subducted into the Indian Ocean subtropical gyre, Deep Sea-Res.-Pt. II, 49, 1441-1457, 2002.

Key, R. M., Tanhua, T., Olsen, A., Hoppema, M., Jutterström, S., Schirnick, C., van Heuven, S., Kozyr, A., Lin, X., Velo, A., Wallace, D. W. R., and Mintrop, L.: The CARINA data synthesis project: introduction and overview, Earth Syst. Sci. Data, 2, 105121, doi:10.5194/essd-2-105-2010, 2010.

Lee, K., Choi, S.-D., Park, G.-H., Wanninkhof, R., Peng, T.-H., Key, R. M., Sabine, C. L., Feely, R. A., Bullister, J. L., Millero, F. J., and Kozyr, A.: An updated anthropogenic $\mathrm{CO}_{2}$ inventory in the Atlantic Ocean, Global Biogeochem. Cy., 17, 1116, doi:10.1029/2003GB002067, 2003. 
Levine, N. M., Doney, S. C., Wanninkhof, R., Lindsay, K., and Fung, I. Y.: Impact of ocean carbon system variability on the detection of temporal increases in anthropogenic $\mathrm{CO}_{2}$, J. Geophys. Res., 113, C03019, doi:10.1029/2007JC004153, 2008.

Lewis, E. L. and Wallace, D. W. R.: Program developed for $\mathrm{CO}_{2}$ system calculations, ORNL/CDIAC-105, Carbon dioxide information analysis center, Oak Ridge National Laboratory, U.S. Department of Energy, Oak Ridge, 1998.

Lischka, S., Büdenbender, J., Boxhammer, T., and Riebesell, U.: Impact of ocean acidification and elevated temperatures on early juveniles of the polar shelled pteropod Limacina helicina: mortality, shell degradation, and shell growth, Biogeosciences, 8, 919-932, doi:10.5194/bg-8-919-2011, 2011.

Lovenduski, N. S., Gruber, N., Doney, S. C., and Lima, I. D.: Enhanced $\mathrm{CO}_{2}$ outgassing in the Southern Ocean from a positive phase of the Southern Annular Mode, Global Biogeochem. Cy., 21, GB2026, doi:10.1029/2006GB002900, 2007.

McCartney, M. S.: Subantarctic Mode Water, in: A Voyage of Discovery, edited by: Angel, M., Pergamon, Elmsford, New York, 103-119, 1977.

McNeil, B. I. and Matear, R. J.: Southern Ocean acidification: A tipping point at $450 \mathrm{ppm}$ atmospheric $\mathrm{CO}_{2}$, P. Natl. Acad. Sci., 105, 18860-18864, 2008.

McNeil, B. I., Tilbrook, B., and Matear, R.: Accumulation and uptake of anthropogenic $\mathrm{CO} 2$ in the Southern Ocean, south of Australia between 1968 and 1996, J. Geophys. Res., 106, 3143131445, 2001.

McNeil, B. I., Metzl, N., Key, R. M., Matear, R. J., and Corbiere, A.: An empirical estimate of the Southern Ocean air-sea $\mathrm{CO}_{2}$ flux, Global. Biogeochem. Cy., 21, GB3011, doi:10.1029/2007GB002991, 2007.

Mehrbach, C., Culberson, C. H., Hawley, J. E., and Pytkowicz, R. M.: Measurement of the apparent dissociation constants of carbonic acid in seawater at atmospheric pressure, Limnol. Oceanogr., 18, 897-907, 1973.

Mémery, L., Arhan, M., Alvarez-Salgado, X. A., Messias, M.-J., Mercier, H., Castro, C. G., and Ríos, A. F.: The water masses along the western boundary of the south and equatorial Atlantic, Prog. Oceanogr., 47, 69-98, 2000.

Metzl, N., Tilbrook, B., and Poisson, A.: The annual $\mathrm{fCO}_{2}$ cycle and the air-sea $\mathrm{CO}_{2}$ flux in the sub-Antarctic Ocean, Tellus, 51B, 849-861, 1999.

Mintrop, L., Perez, F. F., Gonzalez-Davila, M., Santana-Casiano, M. J., and Kortzinger, A.: Alkalinity determination by potentiometry: intercalibration using three different methods, Cienc. Marinas, 26, 23-37, 2000.

Murata, A., Kumamoto, Y., Sasaki, K.'I., Watanabe, S., and Fukasawa, M.: Decadal increases of anthropogenic $\mathrm{CO}_{2}$ in the subtropical South Atlantic Ocean along $30^{\circ} \mathrm{S}$, J. Geophys. Res., 113, C06007, doi:10.1029/2007JC004424, 2008.

Orr, J. C., Fabry, V. J., Aumont, O., Bopp, L., Doney, S. C., Feely, R. A., Gnanadesikan, A., Gruber, N., Ishida, A., Joos, F., Key, R. M., Lindsay, K., Maier-Reimer, E., Matear, R., Monfray, P., Mouchet, A., Najjar, R. G., Plattner, G.-K., Rodgers, K. B., Sabine, C. L., Sarmiento, J. L., Schlitzer, R., Slater, R. D., Totterdell, I. J., Weirig, M.-F., Yamanaka Y., and Yool, A.: Anthropogenic ocean acidification over the twenty-first century and its impact on calcifying organisms, Nature, 437, 681-686, 2005.
Orsi, A. H., Johnson, G. C., and Bullister, J. L.: Circulation, mixing, and production of Antarctic Bottom Water, Prog. Oceanogr., 43, 55-109, 1999.

Peng, T.-H. and Wanninkhof, R.: Increase in anthropogenic $\mathrm{CO}_{2}$ in the Atlantic Ocean in the last two decades, Deep-Sea Res. Pt. I, 57, 755-770, doi:10.1016/j.dsr.2010.03.008, 2010.

Pérez, F. F., Álvarez, M., and Ríos, A. F.: Improvements on the back-calculation technique for estimating anthropogenic $\mathrm{CO}_{2}$, Deep-Sea Res. Pt. I, 49, 859-875, 2002.

Pérez, F. F., Vázquez-Rodríguez, M., Mercier, H., Velo, A., Lherminier, P., and Ríos, A. F.: Trends of anthropogenic $\mathrm{CO}_{2}$ storage in North Atlantic water masses, Biogeosciences, 7, 1789-1807, doi:10.5194/bg-7-1789-2010, 2010.

Peterson, R. G. and Whitworth, T.: The Subantarctic and Polar Fronts in relation to deep water masses through the Southwestern Atlantic, J. Geophys. Res., 94, 10817-10838, 1989.

Revelle, R. and Suess, H.: Carbon dioxide exchange between atmosphere and ocean and the question of an increase of atmospheric $\mathrm{CO}_{2}$ during the past decades, Tellus, 9, 18-27, 1957.

Ríos, A. F., Johnson, K. M., Alvarez-Salgado, X. A., Arlen, L., Billant, A., Bingler, L. S., Branellec, P., Castro, C. G., Chipman, D. W., Roson, G., and Wallace, D. W. R.: Carbon Dioxide, Hydrographic, and Chemical Data Obtained During the R/V Maurice Ewing Cruise in the South Atlantic Ocean (WOCE Section A17, 4 Janurary-21 March 1994), Carbon Dioxide Information Analysis Center, Oak Ridge National Laboratory, ORNL/CDIAC-148, NDP-084, 1-27, 2005.

Ríos, A. F., Vázquez-Rodríguez, M., Padin, X. A., and Pérez, F. F.: Anthropogenic carbon dioxide in the South Atlantic western basin, J. Mar. Syst., 83, 38-44, 2010.

Ríos, A. F., Velo, A., Pardo, P. C., Hoppema, M., and Pérez, F.F.: An update of anthropogenic $\mathrm{CO}_{2}$ storage rates in the western South Atlantic basin and the role of Antarctic Bottom Water, J. Mar. Syst., 94, 197-203, doi:10.1016/j.jmarsys.2011.11.023, 2012.

Sabine, C. L. and Tanhua, T.: Estimation of Anthropogenic $\mathrm{CO}_{2}$ Inventories in the Ocean, Ann. Rev. Mar. Sci., 2, 175-198, doi:10.1146/annurev-marine-120308-080947, 2010.

Sabine, C. L., Key, R. M., Johnson, K. M., Millero, F. J., Poisson, A., Sarmiento, J. L., Wallace, D. W. R., and Winn, C. D. Anthropogenic $\mathrm{CO}_{2}$ inventory of the Indian Ocean, Global Biogeochem. Cy., 13, 179-198, 1999.

Sabine, C. L., Feely, R. A., Gruber, N., Key, R. M., Lee, K., Bullister, J. L., Wanninkhof, R., Wong, C. S., Wallace, D. W. R., Tilbrook, B., Millero, F. J., Peng, T.-H., Kozyr, A., Ono, T., and Rios, A. F.: The Oceanic Sink for Anthropogenic $\mathrm{CO}_{2}$, Science, 305, 367-371, 2004.

Santana-Casiano, J. M., González-Dávila, M., Rueda, M.-J., Llinás, O., and González-Dávila, E.-F.: The interannual variability of oceanic $\mathrm{CO}_{2}$ parameters in the northeast Atlantic subtropical gyre at the ESTOC site, Global Biogeochem. Cy., 21, GB1015, doi:10.1029/2006GB002788, 2007.

Sarmiento, J. L., Gruber, N., Brzezinski, M. A., and Dunne, J. P.: High-latitude controls of thermocline nutrients and low latitude, Nature, 427, 56-60, 2004.

Schneider, A., Tanhua, T., Kortzinger, A., and Wallace, D. W. R.: An evaluation of tracer fields and anthropogenic carbon in the equatorial and the tropical North Atlantic, Deep-Sea Res. Pt. I, 67, 85-97, 2012. 
Talley, L. D.: Antarctic intermediate water in the South Atlantic, edited by: Wefer, G., Berger, H. H., Siedler, G., and Webb, D., in: The South Atlantic: Present and Past Circulation, SpringerVerlag, 219-238, 1996.

Tanhua, T.: Matlab Toolbox to Perform Secondary Quality Control (2nd QC) on Hydrographic Data, ORNL/CDIAC-158, Carbon Dioxide Information Analysis Center, Oak Ridge National Laboratory, U.S. Department of Energy, Oak Ridge, Tennessee, doi:10.3334/CDIAC/otg.CDIAC_158, 2010.

Touratier, F., Azouzi, L., and Goyet, C.: CFC-11, $\Delta{ }^{14} \mathrm{C}$ and ${ }^{3} \mathrm{H}$ tracers as a means to assess anthropogenic $\mathrm{CO}_{2}$ concentrations in the ocean, Tellus, 59B, 318-325, 2007.

van Heuven, S., Pierrot, D., Lewis, E., and Wallace, D. W. R.: MATLAB Program Developed for $\mathrm{CO}_{2}$ System Calculations, ORNL/CDIAC-105b, Carbon Dioxide Information Analysis Center, Oak Ridge National Laboratory, U.S. Department of Energy, Oak Ridge, Tennessee, 2011a.

van Heuven, S. M. A. C., Hoppema, M., Huhn, O., Slagter, H. A., and de Baar, H. J. W.: Direct observation of increasing $\mathrm{CO}_{2}$ in the Weddell Gyre along the Prime Meridian during 1973-2008, Deep-Sea Res. Pt. II, 58, 2613-2635, doi:10.1016/j.dsr2.2011.08.007, 2011b.

Vázquez-Rodríguez, M.: Reconstructing preformed properties and air-sea $\mathrm{CO}_{2}$ disequilibria for water masses in the Atlantic from subsurface data: An application in anthropogenic carbon determination, PhD Thesis of University of Vigo, Spain, 48-60, 2008.

Vázquez-Rodríguez, M., Touratier, F., Lo Monaco, C., Waugh, D. W., Padin, X. A., Bellerby, R. G. J., Goyet, C., Metzl, N., Ríos, A. F., and Pérez, F. F.: Anthropogenic carbon distributions in the Atlantic Ocean: data-based estimates from the Arctic to the Antarctic, Biogeosciences, 6, 439-451, doi:10.5194/bg-6-4392009, 2009a.
Vázquez-Rodríguez, M., Padin, X. A., Ríos, A. F., Bellerby, R. G. J., and Pérez, F. F.: An upgraded carbon-based method to estimate the anthropogenic fraction of dissolved $\mathrm{CO}_{2}$ in the Atlantic Ocean, Biogeosciences Discuss., 6, 4527-4571, doi:10.5194/bgd-6-4527-2009, 2009b.

Vázquez-Rodríguez, M., Pérez, F. F., Velo, A., Ríos, A. F., and Mercier, H.: Observed acidification trends in North Atlantic water masses, Biogeosciences, 9, 5217-5230, doi:10.5194/bg-95217-2012, 2012.

Wallace, D. W. R.: Monitoring global ocean carbon inventories. OOSDP Background Report No. 5, Texas A\&M University, College Station, Texas, USA, 54 pp., 1995.

Wanninkhof, R., Doney, S. C., Bullister, J. L., Levine, N. M., Warner, M., and Gruber, N.: Detecting anthropogenic $\mathrm{CO}_{2}$ changes in the interior Atlantic Ocean between 1989 and 2005, J. Geophys. Res., 115, C11028, doi:10.1029/2010JC006251, 2010.

Waugh, D. W., Hall, T. M., McNeil, B. I., Key, R., and Matear, R. J.: Anthropogenic $\mathrm{CO}_{2}$ in the oceans estimated using transit time distributions, Tellus, 58B, 376-389, doi:10.1111/j.16000889.2006.00222.x, 2006.

Wong, A. P. S., Bindoff, N. L., and Church, J. A.: Large-scale freshening of intermediate waters in the Pacific and Indian oceans, Nature, 400, 440-443, 1999.

Yool, A., Oschlies, A., Nurser, A. J. G., and Gruber, N.: A modelbased assessment of the TrOCA approach for estimating anthropogenic carbon in the ocean, Biogeosciences, 7, 723-751, doi:10.5194/bg-7-723-2010, 2010. 